\title{
Working
}

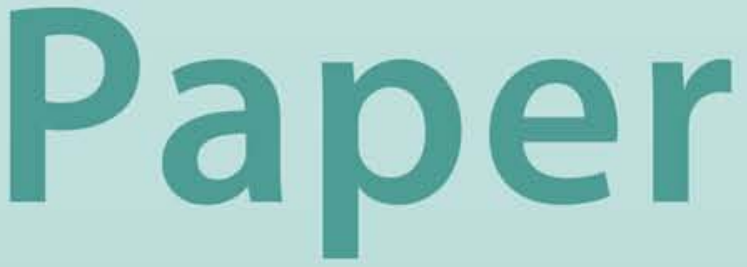




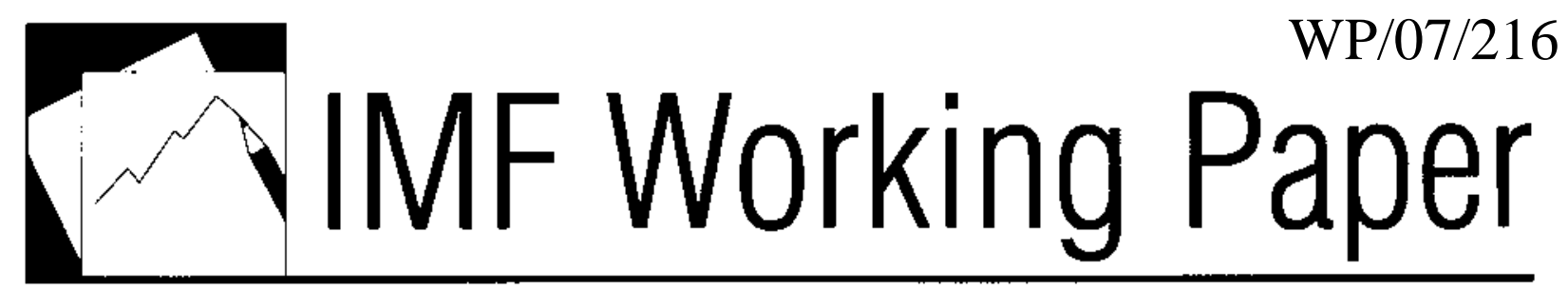

Banking Competition and Capital Ratios

Klaus Schaeck and Martin Čihák 


\title{
IMF Working Paper
}

Monetary and Capital Markets Department

\section{Banking Competition and Capital Ratios}

\author{
Prepared by Klaus Schaeck and Martin Čihák ${ }^{1}$ \\ Authorized for distribution by Mark Swinburne
}

September 2007

\begin{abstract}
This Working Paper should not be reported as representing the views of the IMF. The views expressed in this Working Paper are those of the author(s) and do not necessarily represent those of the IMF or IMF policy. Working Papers describe research in progress by the author(s) and are published to elicit comments and to further debate.

We use data for more than 2,600 European banks to test whether increased competition causes banks to hold higher capital ratios. Employing panel data techniques, and distinguishing between the competitive conduct of small and large banks, we show that banks tend to hold higher capital ratios when operating in a more competitive environment. This result holds when controlling for the degree of concentration in banking systems, inter-industry competition, characteristics of the wider financial system, and the regulatory and institutional environment.
\end{abstract}

JEL Classification Numbers: C41, G21, G28, L11

Keywords: Bank capital ratios; competition; market structure; regulation

Authors’ E-Mail Addresses: Klaus.Schaeck.1@city.ac.uk; mcihak@imf.org

\footnotetext{
${ }^{1}$ This project was completed while Klaus Schaeck was a visiting scholar at the International Monetary Fund. We thank Enrica Detragiache, Karyen Chu, Katja Neugebauer, Bob DeYoung, Gary Fissel, Paul Kupiec, Andrea Sironi, Steven Seelig, Alexander Tieman, Mark Swinburne, Guiliano Iannotta, Marcel Tyrell, Jörg Decressin, Daniel Hardy, Helge Berger, Jochen Schanz, Carlos Alegria, Simon Wolfe, and Masaki Yamada. We also thank seminar and conference participants at the International Monetary Fund, the Federal Deposit Insurance Corporation, the Bank of England, the $2^{\text {nd }}$ European Conference on Financial Regulation and Supervision ("FinLawMetrics") in Milan, the XV ${ }^{\text {th }}$ Tor Vergata Conference, the Paris Finance International Meeting 2006, the University of Southampton, and Bocconi University. All remaining errors are our own.
} 


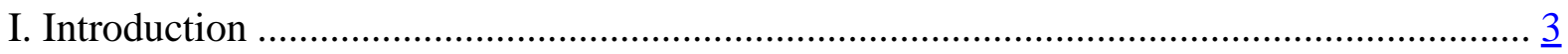

II. Data and Methodology …………………………......................................................

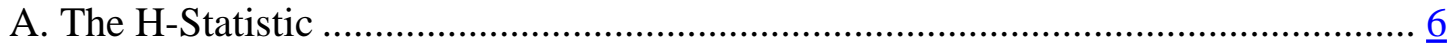

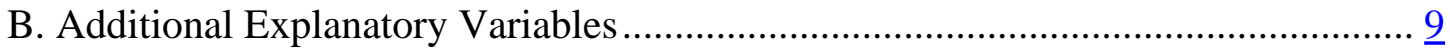

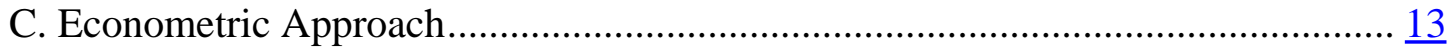

D. Data and Summary Statistics …............................................................

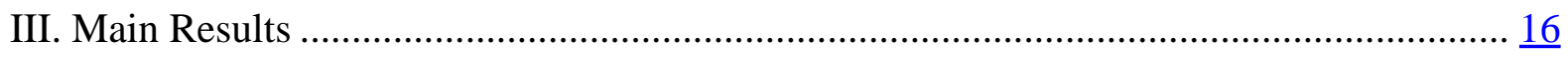

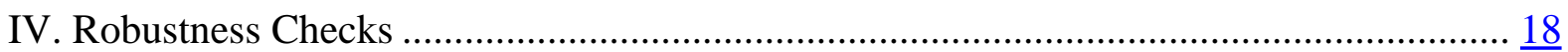

A. The Wider Financial System....................................................................... 18

B. The Institutional and Regulatory Environment.................................................. $\frac{19}{20}$

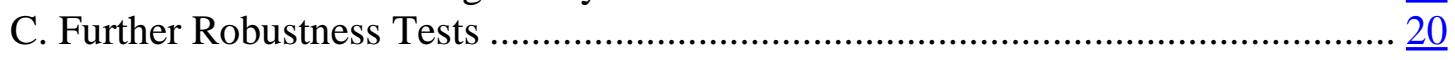

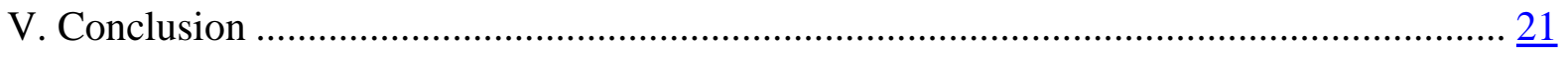

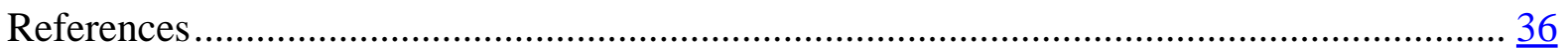

Tables

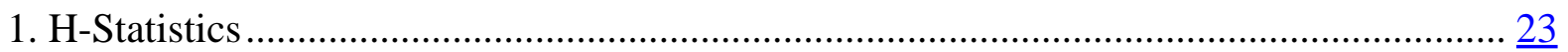

2. Descriptive Statistics..............................................................................................

3. Competition and Capital Ratio................................................................................... 25

4. Quantifying the Effect of Increases in the H-Statistic on the Capital Ratio ........................ 26

5. Competition, Capital Ratio, and the Wider Financial System …………………………..... $\frac{27}{27}$

6. Competition, Capital Ratio, and the Regulatory and Institutional Environment................. $\frac{28}{29}$

7. Further Robustness Checks.......................................................................................... 29

Appendices

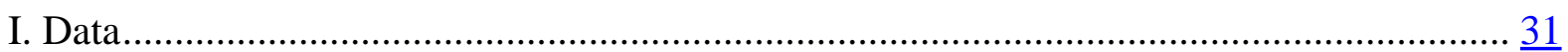

II. Correlation Matrix (Instruments) ……………………………………………….... $\frac{33}{34}$

III. First-Stage Regressions.......................................................................................... $\frac{34}{35}$

IV. Further Robustness Checks........................................................................................ $\frac{35}{4}$ 


\section{INTRODUCTION}

The issue of competition in banking systems has long been a subject of debate among policymakers and regulators. Cross-border mergers and consolidation within national boundaries have prompted concerns about the market power enjoyed by some banks, and the resulting impact on competition among financial institutions and on financial stability (Mishkin, 1999; International Monetary Fund, 2001).

Economic theory has not yet agreed on the implications of increased competition for banking soundness, and, more specifically, bank capital ratios. For example, Smith (1984), Hellman et al. (2000), and Repullo (2004) suggest that increased competition decreases banks' soundness. The key mechanism identified in this literature is that bank managers have an incentive to take excessive risks so as to benefit shareholders at the expense of depositors. By contrast, Caminal and Matutes (2002) demonstrate that monopoly banks with intermediate monitoring costs can be more prone to originate risky loans that give rise to a higher probability of subsequent failure. Similarly, Boyd and de Nicoló (2005) and Boyd et al. (2006) suggest that allowing for competition in lending markets is likely to increase stability; whereas Allen and Gale (2004) highlight that the relationship between competition and stability in banking is multifaceted, with no simple trade-off between the two.

Empirical studies also provide contradictory evidence about the effect of competition and concentration on banking stability. Earlier work implies an inverse relationship between competition and stability (Keeley, 1990; Gan, 2004). However, a growing body of empirical evidence suggests that increased competition, increased concentration and sectors with greater contestability and less activity restrictions are all associated with banking stability (Barth et al., 2004; Beck et al., 2006a, 2006b; Boyd et al., 2006; Schaeck et al., 2006).

In this paper, we show that the seemingly contradictory evidence is attributable to the way competition has been measured in previous studies. Those studies have been usually based on the structureconduct-performance paradigm, which assumes that market structure is related to competitive conduct and that competition can be approximated by the degree of concentration in a banking sector. ${ }^{2}$ However, there are three important problems with this approximation.

(i) Measures of concentration are usually computed using country-level concentration ratios (Beck et al., 2006a, 2006b), even though it is widely accepted that the banking

\footnotetext{
${ }^{2}$ For a review of the early studies see Gilbert (1984). It is often argued that high levels of concentration are a signal for market power enjoyed by incumbent firms with uncompetitive behavior, thereby giving rise to inefficiencies (Demirgüç-Kunt et al., 2004). However, an alternative view, the so-called efficient-structure theory, stresses that more efficient firms tend to operate at lower costs and therefore increase market share (Demsetz, 1973).
} 
industry has become globalized and that financial institutions compete internationally (Shaffer, 2004b). Thus, the definition of a banking market using national boundaries in the earlier studies may not be appropriate. Also, the definition of the banking industry within national boundaries is increasingly blurry.

(ii) The direction of causality running from structure to conduct is not clear (Vesala, 1995).

(iii) The industrial organization literature shows that measures of market structure, such as the number of institutions and concentration ratios, are not necessarily related to the level of competitiveness in an industry (Baumol et al., 1982; Bikker, 2004).

These doubts about the strength of the link between concentration and competitive conduct are substantiated by a growing body of empirical evidence (Claessens and Laeven, 2004; Demirgüç-Kunt et al., 2004; Beck et al., 2006a, 2006b; Schaeck et al., 2006). For this reason, Berger et al. (2004, p. 445) conclude that it is inappropriate to rely on concentration to assess the degree of competition in banking and that more research is "clearly needed."

This paper assesses the impact of bank competition and concentration on bank capital ratios using bank-level data. Specifically, we analyze the relation between the Panzar and Rosse (1987) H-Statistic, as a measure for competition, and banks' capital ratios for more than 2,600 banks from ten European countries from 1999-2004.

We focus on the European banking sector because this banking market has been subject to extensive deregulation following the Second Banking Coordination Directive. This Directive creates a level playing field for competition among banks by allowing them to pursue different lines of business, such as commercial banking, investment banking, insurance and other financial services, and by granting them a 'single passport' to operate across all member countries of the European Union. In our opinion, Europe therefore offers a fertile ground for investigating the effect of competition on bank capitalization.

Our approach differs from previous studies in a number of respects. First, to the best of our knowledge this is the first study to relate a direct measure of competition conduct, the $\mathrm{H}$-Statistic, to bank capital ratios using a cross-sectional time-series dataset. Second, we disentangle the relationship between competition and concentration by simultaneously considering variables that capture both competition and concentration. Third, due to the use of panel data on the bank level, our approach has a considerably improved statistical power compared to previous cross-country studies that focus on systemic crises and estimate logit models where stability is assumed to be either present or absent (Demirgüç-Kunt and Detragiache, 2002). To that extent, our approach recognizes that bank failures can occur without a banking system experiencing systemic strain. Fourth, unlike previous studies, we take account of the endogeneity of competition, concentration, banks' market shares, and bank capital ratios. 
Our results indicate that banks hold more capital as a buffer against default when operating in a more competitive environment. This finding holds when we control for competition from other agents, and when we take the regulatory and institutional environment into consideration. Furthermore, we perform robustness tests including alternative measures of competition and concentration, an alternative dependent variable, clustering of standard errors at the country level, and alternative samples. All these checks corroborate our result concerning the positive relation of the $\mathrm{H}$-Statistic with the capital ratio. Thus, our results empirically substantiate that competition is positively linked with bank soundness at the firm level. On the other hand, we find no consistent relationship between concentration and capital ratios. Our study underscores that normative analyses concerning policy implications for regulation, which are derived from the assumption that competition is detrimental to bank soundness, ought to be reexamined.

The structure of the paper is as follows. Section II presents the variables and the methodology, while Section III contains the main results. Section IV extends the analysis by taking into account characteristics of the wider financial system and the regulatory and institutional environment. We offer concluding remarks in Section V.

\section{Data AND Methodology}

We investigate the effect of banking sector competition on banks' capital ratios (as a measure of soundness), while controlling for bank concentration, the level of risk faced by banks, and other factors that are likely to impact capital ratios. ${ }^{3}$ Specifically, we test the hypothesis that increased competition is associated with banks having higher capitalization. Virtually all banks today are subject to minimum regulatory capital requirements (and all the European banks in our sample face a uniform minimum capital requirement for regulatory capital of at least eight percent of risk-weighted assets). However, there are reasons for banks to hold more than the required minimum.

Theoretical studies suggest that competition may be one of the reasons for banks doing so. For example, Bolt and Tieman (2004) develop a model in which commercial banks compete through setting acceptance criteria for granting loans. By easing its acceptance criteria, a bank faces a trade-off between attracting a greater demand for loans, thus making higher perperiod profits, and a deterioration in the quality of its loan portfolio, thereby tolerating a higher risk of failure. One of the results of their model is that it is beneficial for a bank to hold more equity in a competitive environment than prescribed by the regulator, even though issuing equity is more expensive than attracting deposits. The rationale is that although

\footnotetext{
${ }^{3}$ We focus on bank capital ratios because introduction of the Basel Accord in 1988 has made banks increasingly focus on managing their capital base as a buffer against default. Moreover, it is well known that default risk of banks is directly related to the risk inherent in a bank's asset portfolio and the bank's capitalization (Martin, 1977).
} 
additional equity lowers per-period profits, it prolongs the expected lifetime of the bank and thus the expected stream of future profits. Similarly, Allen et al. (2005) build a model suggesting that equity capital may be higher in situations with highly competitive credit markets when good lending opportunities are scarce.

We measure capitalization by the capital ratio, defined as equity to total assets. Supervisory agencies typically focus on the capital adequacy ratio, defined as (regulatory) capital to riskweighted assets. The capital adequacy ratio uses arbitrary risk-weights to adjust for differences in the degrees of risk arising for banks from the various groups of assets. We adjust for such differences as part of our regression approach rather than as part of the measure of capitalization. Our approach allows us to better distinguish whether a bank's higher capitalization indicates its increased soundness, or whether it is merely a reflection of the higher risks it is facing.

\section{A. H-Statistic}

The Panzar and Rosse (1987) H-Statistic is designed to discriminate between competitive, monopolistically competitive, and monopolistic markets. Claessens and Laeven (2004) argue that the H-Statistic is a more appropriate measure for the degree of competition than other proxies for competitive conduct, and Shaffer (2004a) notes that the H-Statistic is superior to other measures of competition, because it is derived from profit-maximizing equilibrium conditions. Finally, Cetorelli (1999) underscores that it is inappropriate to rely on concentration measures when markets are contestable and if the industry is undergoing major restructuring, suggesting that competition can only be observed by looking at bank-level data.

Given this theoretical appeal, an increasing body of empirical work employs this statistic to test for competition in banking (Shaffer, 2004b; Molyneux et al., 1994; Vesala, 1995; Bikker and Haaf, 2002; Claessens and Laeven, 2004).

The measure is based on a general banking market model which determines equilibrium output and the number of institutions by maximizing profits at both the firm and the industry level. Bank i maximizes profit when marginal revenue equals marginal cost

$$
R_{i}^{\prime}\left(x_{i}, n, z_{i}\right)-C_{i}^{\prime}\left(x_{i}, w_{i}, t_{i}\right)=0
$$

whereby $R_{i}^{\prime}$ denotes revenues and $C_{i}^{\prime}$ refers to costs of bank i. Output of bank i is denoted by $\mathrm{xi}$ and $\mathrm{n}$ is the number of institutions. The term wi is the vector of $\mathrm{m}$ input prices for bank $\mathrm{i}$ and zi and ti are vectors of exogenous variables that shift the revenue and cost functions respectively. Adopting a similar line of reasoning for the market level yields the following equation such that the zero profit condition constraint is maintained

$$
R_{i}^{*}\left(x^{*}, n^{*}, z\right)-C_{i}^{*}\left(x^{*}, w, t\right)=0 \text {. }
$$


The asterisks denote equilibrium values. $\mathrm{H}$ measures market power by the extent to which changes in factor input prices, $\left(d w_{k_{i}}\right)$, translate into equilibrium revenues, $\left(d R_{i}^{*}\right)$ earned by bank $\mathrm{i}$. In short, $\mathrm{H}$ is a measure of the sum of the elasticities of the reduced-form revenues with respect to factor prices and is computed as

$$
H=\sum_{k=1}^{m} \frac{\partial R_{i}^{*}}{\partial w_{k_{i}}} \frac{w_{k_{i}}}{R_{i}^{*}} .
$$

Considering that cost functions are homogeneous of degree one in input prices, a proportional increase in factor prices is mirrored by an equiproportional increase in revenue under perfect competition. Given that a competitive firm is constrained to zero economic profit at the initial price vector, it must adjust output prices to pass on the entire cost increase to remain solvent. Thus, in long-run equilibrium, a bank's revenue must change by the same percentage as its costs, and so by the same percentage as its input prices, so $\mathrm{H}=1$. Under monopolistic competition, revenues will increase less than that. In the monopoly case, increases in factor input prices will not be reflected in revenue or will even decrease revenue.

Vesala (1995) shows that the H-Statistic is an increasing function of the demand elasticity, suggesting that as $\mathrm{H}$ increases, less market power is exercised on the part of the banks. This implies that the magnitude of the $\mathrm{H}$-Statistic can serve as a measure for the degree of competition assuming that the bank faces a demand with constant elasticity and a CobbDouglas production technology. As a consequence, a continuous interpretation is appropriate (Claessens and Laeven, 2004).

The magnitude of $\mathrm{H}$ can be interpreted in the following way:

$$
\begin{array}{ll}
\mathrm{H} \leq 0 & \begin{array}{l}
\text { Indicates monopoly equilibrium, perfectly colluding oligopoly or } \\
\text { conjectural variations short-run oligopoly }
\end{array} \\
0<\mathrm{H}<1 & \text { indicates monopolistic competition } \\
\mathrm{H}=1 & \text { indicates perfect competition }
\end{array}
$$

To obtain value for the H-Statistic for each year, it is common in the literature to estimate a reduced-form model whereby output is regressed on factor input prices and some controls that shift the bank's revenue function. We compute the H-Statistic using a setup similar to Bikker and Haaf (2002) and Claessens and Laeven (2004). In addition, we split the sample into large and small institutions since potential differences in the way small and large banks compete would bias our measure of competition. Small banks often operate on a locally constrained basis and tend to face stronger competition from other small banks in retail banking operations. In contrast, large banks compete in different lines of business, e.g. 
corporate and investment banking, and compete globally. We use a cut-off point of $450 \mathrm{~m}$ EUR to distinguish between small and large institutions. ${ }^{4}$

We estimate the equation (4) for each country for small and large banks for the years 19992004,

$$
\begin{aligned}
& \ln (R)=\alpha+\beta_{1} \ln \left(W_{1}\right)+\beta_{2} \ln \left(W_{2}\right)+\beta_{3} \ln \left(W_{3}\right) \\
& +\gamma_{1} \ln \left(Y_{1}\right)+\gamma_{2} \ln \left(Y_{2}\right)+\gamma_{3} \ln \left(Y_{3}\right)+\gamma_{4} \ln \left(Y_{4}\right)+\varepsilon
\end{aligned}
$$

where $R$ is the ratio of total revenue to total assets (proxy for output price of loans and other services). ${ }^{5}$ This variable includes total interest revenue, fee income, commission income, and other operating income. As noted by Claessens and Laeven (2004), the reason for including all these forms of income is that banks compete in different types of activities, not only interest revenue generating activities. The variable $W_{1}$ is the ratio of interest expenses to total deposits and money market funding (proxy for input price of deposits), $W_{2}$ is the ratio of personnel expenses to total assets (proxy for input price of labor), and $W_{3}$ is the ratio of other operating and administrative expense to total assets (proxy for input price of equipment and fixed assets). To take account of risk-taking behavior and size, $Y_{1}$ captures the ratio of deposits to deposits and money market funding, $Y_{2}$ is the ratio of net loans to total assets, $Y_{3}$ is the ratio of equity to total assets, and ${ }^{{ }_{4}}$ captures bank size, measured as total balance sheet assets. All variables enter the equation in logs. The H-Statistic is calculated as the sum of the coefficients $\beta_{1}+\beta_{2}+\beta_{3}{ }^{6}$.

For robustness tests performed in Section 4.3, we also calculate the H-Statistic with the ratio of interest revenue to total assets as dependent variable in (4) and subsequently recalculate the $\mathrm{H}$-Statistics where we omit the equity ratio to avoid correlation between the H-Statistic and the equity ratio affecting our inferences.

\footnotetext{
${ }^{4}$ This cut-off point is aligned with the literature on small banks in Europe (Mercieca et al., 2007).

${ }^{5}$ Molyneux et al. (1996) have found that this functional form gives very similar results as a translog specification.

${ }^{6}$ Note that this method does not differentiate between competition in loan and deposit markets. This is consistent with the commonly used intermediation approach for measuring bank output, which treats banks as intermediators of services rather than producers of deposit accounts and loans. Thus, the values of loans and investments are used as output measures, whereas labor and capital are inputs to the process of intermediation. Consequently, operating costs plus interest costs are relevant cost measures.
} 
Molyneux et al. (1994) point out that the H-Statistic assumes long-run equilibrium. We perform the following analysis to investigate long-run equilibrium and estimate Equation (4) with the pretax return on assets as a dependent variable. ${ }^{7}$

$$
\begin{aligned}
& \ln (R O A)=\alpha+\beta_{1} \ln \left(W_{1}\right)+\beta_{2} \ln \left(W_{2}\right)+\beta_{3} \ln \left(W_{3}\right) \\
& +\gamma_{1} \ln \left(Y_{1}\right)+\gamma_{2} \ln \left(Y_{2}\right)+\gamma_{3} \ln \left(Y_{3}\right)+\gamma_{4} \ln \left(Y_{4}\right)+\varepsilon
\end{aligned}
$$

The equilibrium statistic is also calculated as $\beta_{1}+\beta_{2}+\beta_{3}$. We test for $E=0$, using an F-test. Long-run market equilibrium indicates that the sum of the coefficients on the input prices equals zero. In other words, the test aims to establish whether input prices are uncorrelated with industry returns since a competitive system will equalize risk-adjusted rates of return across banks in equilibrium. If this hypothesis is rejected, the market is assumed to be in disequilibrium. We note that Shaffer (2004b) underscores that rejection of equilibrium does not necessarily invalidate the inferences based on $\mathrm{H}$ for the purpose of our study, because observing values of $\mathrm{H}>0$ (which holds for most of the observations) indicates that the long-run equilibrium assumption is not strictly necessary for the interpretation of the $\mathrm{H}$-Statistic. He stresses that disequilibrium suggests that the industry develops dynamically.

\section{B. Additional Explanatory Variables}

We use BankScope data for all bank-specific variables. ${ }^{8}$ We calculate the 3-bank concentration ratio for each country for each year during 1999-2004. ${ }^{9}$ We consider banklevel, regulatory, institutional, and macroeconomic control variables that might have an effect on bank capital. Given that credit risk is the main source of risk in most banking systems (World Bank and International Monetary Fund, 2005), we control for the ratio of loan loss provisions to net loans as a measure for credit risk in banks. Flannery and Rangan (2004) find a positive relation of asset risk and profitability with the capital buffer. Hence, we include the ratio of profit before tax to total assets to account for this finding.

To adjust for market discipline, we include the interbank ratio. ${ }^{10}$ This reflects the assertion that other banks have the ability to monitor their peers in the interbank market (Nier and

\footnotetext{
${ }^{7}$ Following Claessens and Laeven (2004), we calculate the dependent variable $R O A^{\prime}=\ln (1+R O A)$ where ROA is the unadjusted return on assets.

${ }^{8}$ BankScope is a commercial database for bank data based on financial statement information provided by Bureau van Dijk. BankScope has been extensively used in the banking literature and provides harmonized data that permit cross-country comparisons.

${ }^{9}$ Subsequently, we also use the Herfindahl-Hirschman index and the log of the ratio of the number of banks to the population of a country as alternative measures for market structure.

${ }^{10}$ The interbank ratio is the ratio of money lent to other banks divided by money borrowed from other banks. A ratio greater than one indicates that the bank is a net placer in the interbank market and is therefore more liquid.
}

(continued...) 
Baumann, 2006) - and they also have the incentive, because interbank deposits are typically not covered by deposit protection schemes. We expect this ratio to be positively related to the banks’ capital ratio.

A further consideration concerns bank size. Ayuso et al. (2004) offer evidence that larger banks hold lower levels of capital. This finding is aligned with Demsetz and Strahan (1997) who report that larger intermediaries are better able to benefit from diversification and therefore operate with lower capital ratios. We use total assets (log) and anticipate an inverse relation between size and capital.

We also include the market share of each bank. Banks that are large relative to the system might be subject to regulatory forbearance in case of difficulties and may hold less capital (Mishkin, 1999). We use a log transformation for the market share variable as this variable is highly skewed.

We further test for the effect of asset growth to control for the possibility that a higher capital ratio simply reflects an adjustment of bank capital ratios to the volume of the bank's business. We anticipate this variable to enter the equation with a positive sign.

Since the level of capital may also depend on macroeconomic conditions, we include GDP growth, inflation, and the real interest rate. Capital ratios may be procyclical if banks use an expansionary macroeconomic environment to accumulate capital (Laeven and Majoni, 2003).

Controlling for inflation is also important as Hortlund (2005) finds an inverse association between inflation and bank capital. We expect a negative sign for the coefficient of inflation. In addition, rising real interest rates adversely affect borrowers' ability to repay their bank loans. This can negatively impact on capital ratios if many borrowers default, a relation that is well documented in the literature on systemic banking crises (Demirgüç-Kunt and Detragiache, 1998). Therefore, we expect a negative link between real interest rates and capital ratios. Finally, we use GDP per capita to control for the level of economic environment as we anticipate that a higher level of economic development proxies for sophisticated procedures regarding bank oversight (Demirgüç-Kunt and Detragiache, 1998).

The wider financial system

We employ additional control variables that provide information on the wider financial system and the regulatory and institutional environment.

By contrast, if the ratio is below one, the bank is a net borrower in the interbank market and heavily reliant on interbank deposits to fund its assets. 
- Measures for the characteristics of the wider financial system. The ratio of nonperforming loans to total loans in the banking system is a key measure for the overall stability of a country's banking system. ${ }^{11}$ We hypothesize that the effect of competition on capital ratios may be larger in magnitude in countries with a higher proportion of non-performing loans since bank charter values will suffer.

Consequently, incentives for banks to behave prudently will be less pronounced as declining charter values are commonly associated with increased risk (Keeley, 1990). Thus, if bankers 'gamble for resurrection' in episodes of sustained stress, this relation is likely to be negative.

- The effect of stock market development. A well-developed stock market may change the competitive environment in which banks operate. Indeed, enterprises can raise funds on capital markets and these funds are close substitutes for bank loans. ${ }^{12}$ Dinç (2000) shows that capital market competition decreases the threshold level of borrowers' creditworthiness by which banks originate loans and commit to supporting even low quality borrowers. Thus, a highly developed stock market provides enterprises with an opportunity to raise funds directly rather than obtaining funds from banks. When the banks' role as mobilizers of savings from the non-financial sector is declining, they have an incentive to compete more heavily to retain customers. If banks therefore increasingly engage in risk-taking behavior as a result of this process of disintermediation, their capital ratios may be affected negatively. An inverse relation between stock market development and capital ratios is therefore anticipated.

- The relative size of the banking sector to the stock market. This is also likely to affect the capital ratio. Bikker (2004) offers evidence that the importance of traditional intermediation activities has been declining in Europe and that banks are therefore expanding into non-traditional lines of business. This, however, may be a precarious strategy. Mercieca et al. (2007) show that performance measures are inversely related to moving into non-interest income generating activities in Europe. If bank performance is deteriorating and losses are sustained in these new lines of business, capital ratios may suffer ultimately. Consequently, an inverse relationship between this variable and the capital ratio can be anticipated.

- Inter-industry competition from life insurers. Such competition is an important consideration since life insurers directly compete with banks for asset allocation

\footnotetext{
${ }^{11}$ This ratio has been identified as a “core financial soundness indicator” (International Monetary Fund, 2004).

${ }^{12}$ Another reason why the effect of stock market development is an important consideration is that the banks' ability to raise equity capital will be limited in the absence of a sophisticated capital market. This is due to the fact that the cost of raising bank capital will increase if no well-developed stock market exists (Nier and Baumann, 2006).
} 
(Claessens and Laeven, 2004). We hypothesize that a larger ratio of life insurance premiums collected divided by GDP signals more competition from life insurers. We expect a negative impact of this ratio on banks' capital ratios.

- The growth rate of domestic credit to the private sector to GDP. We include this because Ruckes (2004) illustrates that bank competition and also credit standards vary systematically with the business cycle. Most studies suggest a negative relationship between credit growth and capital ratios, suggesting that excessive lending is associated with the relaxing of capital ratios (Dell'Ariccia and Marquez, 2006).

- The density of banks. This is occasionally used as a measure for market structure (Claessens and Laeven, 2004). We therefore include the log of the ratio of banks to population into the regressions, and anticipate that a sector with a higher banking density is more competitive. If the number of banks serves as proxy for competition and if the hypothesis by Keeley (1990) that competition adversely affects prudent behavior by banks simultaneously hold true, we can expect an inverse relation between the number of banks and the capital ratio.

The regulatory and institutional environment

We also consider variables that provide information on the regulatory and institutional environment to control for national characteristics that previous research has identified as being closely related to banking sector performance.

- $\quad$ The judicial system. Several studies highlight the linkages between the origin of a country's judicial system and financial sector development, since substantial differences exist regarding protection of creditor rights. Such rights provide the critical underpinning for financial contracting (La Porta et al., 1998). According to this view, countries with a legal system that protects the elite and favors reallocation of resources to the elite will have less competitive financial systems. We therefore introduce three dummy variables that take on the value of one if a country has French, Scandinavian, or British legal origin or zero otherwise. We omit the dummy for German legal origin to avoid perfect collinearity.

- The institutional environment. Similarly, the strength of the institutional environment might have an influence on the way banks manage their capital. Thus, the strength of institutions is a further key ingredient of a well-functioning financial system. We therefore include the rule of law as a measure for the strength of the institutional environment (Demirgüç-Kunt and Detragiache, 2002). The index is increasing in the quality of institutions and ranges between zero and six. We hypothesize that capital ratios are higher in a stronger institutional environment. 
- Deposit insurance. Extensive research has examined deposit insurance and bank risk. The majority of these studies argue that the presence of explicit deposit insurance and extensive coverage of depositors undermines market discipline (Demirgüç-Kunt and Detragiache, 2002). To account for this source of moral hazard, we introduce an updated version of the moral hazard index developed by Demirgüç-Kunt and Detragiache (2002). This index is computed as the first principal component obtained from eleven deposit insurance features, with higher values indicating increased moral hazard. Thus, higher values of the index are anticipated to be inversely related to capital ratios.

- Capital regulatory index. The level of capital is obviously influenced by regulatory requirements. Therefore, we control for a capital regulatory index proposed by Barth et al. (2004), a summary index calculated from initial capital stringency and overall capital stringency as detailed in the Data Appendix. It captures information on (i) whether the capital requirements appropriately reflect risk elements, (ii) whether market value losses are deducted prior to the calculation of the capital adequacy ratio, and (iii) which types of funds are employed to establish a bank. Higher levels of capital stringency are anticipated to increase the capital buffer as greater stringency encourages prudent behavior.

- Shareholders' influence. The capital ratio is also likely to depend on shareholders' influence (Nier and Baumann, 2006). To account for this effect, we use a shareholder rights index obtained from La Porta et al. (1998). We do not have a strong prior about the sign of this coefficient. On one hand, bank managers that are better controlled by shareholders can be expected to behave more prudently, and therefore build higher capital buffers. However, if the corporate governance systems closely align the interests of managers and shareholders, managers will avoid raising capital as this dilutes the stakes of existing shareholders (Myers and Majluf, 1986).

- Bank ownership structure. Previous work by Berger et al. (2005) reports that bank ownership structure matters for bank performance and bank stability. We therefore incorporate two variables, obtained from La Porta et al. (2002) and Barth et al. (2001) that capture government and foreign ownership, respectively. Government-owned banks are known to exhibit higher proportions of non-performing loans (Berger et al., 2005). By contrast, foreign-owned institutions are often considered to be characterized by efficiency in risk management procedures and by more sophisticated corporate governance systems (Bongini et al., 2001). Therefore, they can be expected to have higher capital ratios.

\section{Econometric Approach}

An important feature of our approach is that we control for possible endogeneity of the measures of concentration and competition. Endogeneity can arise when causality is 
reversed, i.e. when concentration and competition themselves depend on capital ratios. Similarly, an individual bank's market share is also likely to be endogenous. Reverse causality could arise if a large, well-capitalized bank decides to pursue a growth strategy and merges with another large bank, thereby increasing industry concentration and the individual bank's market share. This would imply a positive relationship between bank capital, the respective concentration measures, and the market share. By contrast, a negative association between these variables is also possible. Demsetz and Strahan (1997) put forward the view that larger banks are better able to diversify and tend to operate with lower levels of capital, while Flannery and Rangan (2004) highlight that larger banks have better access to wholesale markets, which allows them to hold lower levels of capitalization. Thus, it can be assumed that lower capital ratios tend to be associated with greater degrees of concentration in banking systems. Similarly, banks with a low capital ratio can be assumed to have lower charter values and may be therefore more prone to engage in risk-taking behavior (Keeley, 1990). This would be reflected in a negative association between the capital ratio and competition.

In addition, Nier and Baumann (2006) argue that the level of deposits obtained from other banks is also likely to be endogenous. They highlight that banks holding little capital may have to rely on the interbank market to obtain funding. Since an increasing reliance on interbank deposits will decrease the interbank ratio, one could anticipate a positive relationship between bank capital and the interbank ratio. By contrast, if depositors consider a bank to be risky due to a low level of capital, banks could face higher costs for funding, which would decrease reliance on interbank deposits. This would imply an inverse association of bank capital with the interbank ratio.

To address the likely endogeneity, we turn to instrumental variable techniques, using a 2SLS estimator. We employ entry restrictions, activity restrictions, and banking freedom as instruments to explain the H-Statistic, the concentration measures and the market share in the first stage (see Data Appendix). Entry restrictions are an important measure for the contestability of a banking system. This variable is constructed as an index and takes on values between (1) and (8), whereby a higher index value indicates greater entry restrictions.

Activity restrictions are a further key determinant for the scope of a bank's business. This indicator is constructed as an index and takes on values between (1) and (4) for four categories that capture information as to whether banks can engage in securities, insurance, and real estate activities, and if they can hold stakes in non-financial institutions. The activities are classified as unrestricted (1), permitted (2), restricted (3), or prohibited (4), with possible index variation between four and sixteen. Higher values indicate greater restrictions on bank activities and non-financial ownership and control.

We use banking freedom as a broad indicator for the openness of a banking system. The index provides information on whether foreign banks are allowed to operate freely, difficulties faced when setting up domestic banks, and on government influence over the 
allocation of credit. The indicator is constructed as an index ranging from (1) to (5), whereby higher values indicate fewer restrictions. Thus, these instruments directly affect competition, but cannot be assumed to immediately impact on the capital level.

We use the cost to income ratio, ${ }^{13}$ the ratio of pretax profit to total assets, and the log of total assets to instrument the interbank ratio (Nier and Baumann, 2006). These variables are unlikely to be controlled by a bank over a one-year horizon and can therefore be considered exogenous. ${ }^{14}$ To test the hypothesis that competition affects banks' capital ratios, we use a random-effects model and estimate the capital ratio ${ }^{y}$ for bank ${ }^{i}$ at time $t_{\text {as follows }}{ }^{15}$

$$
y_{i t}=\mu+\beta_{1} c_{i t}^{\prime}+\beta_{2} x_{i t}^{\prime}+\alpha_{i}+\varepsilon_{i t}
$$

where $\varepsilon_{i t} \sim$ i.i.d. $\left(0, \sigma_{\varepsilon}^{2}\right) ; \alpha_{i} \sim$ i.i.d. $\left(0, \sigma_{\alpha}^{2}\right)$. The error term consists of $\alpha_{i}$ and ${ }^{\varepsilon_{i t}}$, the former denoting a bank-specific time-invariant component and the latter capturing the remaining disturbance. The measures of competition and concentration are captured by the vector $C$. The vector ${ }^{x}$ contains information on the regulatory, institutional, and macroeconomic control variables. ${ }^{\beta_{1}}$ and $\beta_{2}$ denote the estimated parameters.

\section{Data and Summary Statistics}

We obtain bank data from BankScope for 1999-2004. We also employ macroeconomic variables obtained from the World Bank's Development Indicators and information on the regulatory and institutional environment to control for the environment in which banks operate. This information is provided by Barth et al. (2001, 2004), Beck et al. (2000, 2006a, 2006b) and by the Heritage Foundation. The variables on regulation and market structure obtained from the databases provided by Barth et al. (2001, 2004) and Beck et al. (2000, 2006a, 2006b) typically refer to the beginning of our sampling period in 1999 . The absence

\footnotetext{
${ }^{13}$ The cost to income ratio is defined as the ratio of overhead cost divided by the sum of net interest revenue and other operating income.

${ }^{14}$ Correlation matrices for the instruments and the instrumented variables, and the results for the first stage regressions can be obtained from the authors on request. All first stage regressions confirm the validity of our instruments.

${ }^{15}$ We also considered estimating a model for panel data with fixed effects. However, some of our explanatory variables do not vary over time and would be dropped by a fixed effects estimator. In particular, regressors that capture the regulatory and institutional environment that are key ingredient for our analysis would be disregarded using a fixed effects approach. Moreover, using a fixed effects approach suggests that the inferences would be conditional upon the values of the bank specific fixed effects. By contrast, the random effects approach is more appropriate when the objective of the study is to draw general inferences with respect to population characteristics. This is due to the fact that the random effects approach is not conditional on the individual bank specific effects (Verbeek, 2004). Consequently, the random effects model is our preferred estimator.
} 
of time variation in these variables is common to the literature and, as pointed out by Barth et al. (2001), does not pose a major problem, because the application of supervision and regulation does not change in the short run and there is a considerable time lag between changes in regulation until such alterations are observable in banking system performance. ${ }^{16}$

Our initial sample contains 24,955 bank-year observations for the EU 15 countries (Austria, Belgium, Denmark, Finland, France, Germany, Greece, Ireland, Italy, Luxembourg, the Netherlands, Portugal, Spain, Sweden, and the United Kingdom) and Switzerland. We include all savings, co-operative, and commercial banks, and apply a number of selection criteria and drop the 1st and 99th percentile of the distribution of the respective variables. To obtain accurate estimates of the H-Statistic, we further delete countries with data for less than 10 banks per year and per size category. ${ }^{17}$ The final sample consists of 18,782 bank-year observations for ten countries (Austria, Belgium, Denmark, France, Germany, Italy, Luxembourg, Sweden, Switzerland, and the United Kingdom). The results for the averaged $\mathrm{H}$-Statistics for the sampling period 1999-2004 for small and large banks, and the $\mathrm{H}$ Statistics computed by Claessens and Laeven (2004) are presented in Table 1.

The H-Statistics indicate that the banking systems in the sample are characterized by monopolistic competition. While Belgium and Denmark exhibit comparatively low levels of competition, Austria, Luxembourg, and Switzerland appear to have the most competitive banking systems in Europe. The number of observations varies for the variables that are available for the econometric analysis (see Table 2). For instance, the interbank ratio, used as a bank-level control in all regressions, restricts the number of observations that can be employed for the regressions to 11,661 observations, since this ratio is not available for all banks. The number of observations decreases further to a maximum of 8,584 observations as we lag our variables by one period to avoid simultaneity.

\section{MAin Results}

We present the main results in Table 3. Setup (1) is our canonical model and we additionally include measures for concentration, the overall level of economic development, bank market share and a number of interaction terms in Setups (2)-(7).

The H-Statistic enters all regressions in Table 3 positively and significantly, indicating that banks hold more capital when competition increases. The positive association between the two variables suggests prudent behavior on the part of the banks when competition stiffens. Moreover, this result is in line with the predictions in theoretical studies by Bolt and Tieman (2004) and Allen et al. (2005).

\footnotetext{
${ }^{16}$ Further details on variable definitions and all data sources are given in the Data Appendix. Correlation matrices for the bank-level and country-level variables can be obtained from the authors on request.

${ }^{17}$ We therefore drop Spain, Netherlands, Ireland, Greece, Portugal, and Finland from the initial sample.
} 
The relation between concentration and bank capital is not clear-cut. The coefficient enters with a positive sign at the one percent level in Setup (2), indicating that banks in more concentrated banking systems hold higher capital ratios than banks in less concentrated banking systems. However, this finding is reversed in Setup (3). Since banks in more concentrated systems tend to be bigger, moral hazard can explain this finding. For instance, Mishkin (1999) suggests that banking systems with a limited number of large institutions are likely to be subject to regulators' 'too big to fail' policies. This, in turn, could encourage large banks to hold less capital. Controlling for concentration does not adversely impact upon the significance of the H-Statistic. This result suggests a reexamination of the nexus between concentration and bank stability put forward in previous work. In Setup (3), we additionally include GDP per capita to control for the level of economic environment. This variable enters significantly with a positive sign, suggesting that banks in more highly developed countries exhibit higher capital ratios. The effect of the H-Statistic on the capital ratio is left unchanged.

We incorporate the market share (log) of individual banks in Setup (4) to control for the relative size of individual institutions, and Setup (5) includes bank asset growth. Both variables remain insignificant. These findings neither support the conjecture that banks that are large relative to the banking system hold lower capital ratios, nor do they suggest that banks that grow in size increase their capital ratios.

We also test for interactions of the overall level of economic development with competitiveness in the banking industry and of GDP per capita with the H-Statistic. ${ }^{18}$ The benchmark effect of the H-Statistic remains positive and significant in Setup (6). The interaction term enters negatively and significantly, indicating that the effect of competition is lower in countries with a higher level of economic development.

To examine the link between competition and concentration explicitly, we employ an interaction term between these two variables in Setup (7). This specification corroborates the finding for the positive benchmark effect of competition on capital and the interaction term enters negatively, indicating that the effect of competition is considerably reduced in concentrated banking systems. This can be explained by moral hazard. Banks in concentrated banking systems may be more likely to be bailed out in case of difficulties (Mishkin, 1999).

Among the bank-specific control variables, we find that the operating profit measure and the interbank ratio tend to go hand in hand with larger capital ratios. We also find some evidence that larger banks hold less capital, which can be explained by better opportunities to diversify. The ratio of loan loss provisions to net loans is positively associated with the

\footnotetext{
${ }^{18}$ Note that the interaction terms between GDP per capita and the H-Statistic and between the H-Statistic and concentration are to be treated as endogenous since individual components of the interaction terms are instrumented.
} 
capital ratio in four out of seven regressions. This result reflects that loan loss provisions are an ex-post measure for the riskiness of an institution. Moreover, loan losses may only be recognized with a time lag, and supervisory and accounting practices for recognizing such losses differ across countries. Among the macroeconomic control variables, we find that GDP growth enters the regressions positively and significantly. While inflation is positively associated with capital ratios in all regressions, the real interest rate is not consistently associated with bank capital.

We illustrate the economic impact of competitive conduct in Table 4, where we quantify the effect of a one percent increase in the H-Statistic on the capital ratio.

Table 4 demonstrates that the impact of competition on the banks' capital ratios is considerable. Evaluated at the median bank's capital ratio, we find that increasing competition by one percent $(0.0032=0.01 * 0.3229)$ increases the capital ratio from 5.6 percent to 5.9 percent (Table 4, column 2). The breakdown by bank size illustrates that the effect is more pronounced for large banks, and that banks ranked at the 25th percentile in terms of their capital ratio exhibit a higher sensitivity to increases in competition.

\section{ROBUSTNESS CHECKS}

This section accounts for characteristics of the wider financial system and the regulatory and institutional environment. We also perform a range of other robustness checks. Due to correlation between the country-level variables, we enter the additional variables one at a time.

\section{A. The Wider Financial System}

Table 5 presents the results of the examination of the effect of allowing for important characteristics of the wider financial system. The results confirm that banks tend to hold higher capital ratios as the level of competition increases. The H-Statistic remains significant at the one percent level in all instances. The key results are:

- $\quad$ As expected, the ratio of non-performing loans to total loans in the banking system exhibits a negative sign (at the one percent significance level).

- $\quad$ Stock market development has a negative and significant impact on capital ratios.

- $\quad$ A declining role of the banking sector relative to the stock market adversely affects capital ratios.

- Inter-industry competition from life insurers is positively and significantly related to banks' capital ratios. 
- Higher credit growth tends to decrease the capital ratio, a result aligned with evidence that capital buffers can suffer as a result of lending booms.

- $\quad$ The log of the ratio of the number of banks to population enters significantly and negatively, consistent with the hypothesis that banks in systems with more banks have lower capital ratios.

- $\quad$ The competitive conduct of banks and the number of banks describe different characteristics of banking systems, a finding well-known in the industrial organization literature (Baumol et al., 1982).

\section{B. The Institutional and Regulatory Environment}

Table 6 shows that our main finding (that banks hold more capital when competition increases) holds even when controlling for origin of a country's judicial system, rule of law, capital regulation, shareholder rights, and bank ownership structure. The H-Statistic is rendered insignificant only when we control for deposit insurance design features.

First, we include the three dummy variables for legal origin to account for the differences in the general institutional framework. The dummies enter the regression significantly, suggesting that a country's legal system has a bearing for the level of capital held by banks. Second, we include rule of law to control for the strength of institutions. The coefficient of the index exhibits a positive and significant sign, indicating indeed that a stronger institutional environment makes banks hold higher capital ratios. Third, the moral hazard index enters positively and significantly, suggesting that deposit insurance can encourage bank managers to hold higher levels of capital which may reflect a commitment that deposit insurance will only be limited to insured depositors (Gropp and Vesala, 2004). While this result stands up against a considerable body of literature highlighting the negative effects arising from deposit insurance, it is not unreasonable. For instance, Hutchinson and McDill (2002) find no consistent effect arising from deposit insurance on the probability of observing systemic banking crises, and Eichengreen and Arteta (2000) also fail to find support for moral hazard attributable to deposit protection. Controlling for deposit insurance design features renders the H-Statistic insignificant. Fourth, introducing the capital regulatory index yields evidence that higher levels of capital stringency are associated with higher capital ratios. Fifth, stronger shareholder rights are also positively related to a bank's capital ratio. Taking the effect of these two variables into consideration has no effect on the $\mathrm{H}$ Statistic. Finally, accounting for the ownership structure of banks shows that foreign-owned banks operate with higher capital levels, while government-owned banks have lower capitalization, but this adjustment does not change our inferences with respect to the relation between competition and capital ratios. 


\section{Further Robustness Tests}

We perform further robustness checks in Table 7. To verify that the results are not driven by the way the H-Statistic is calculated, we use alternative measures of competition. We subsequently employ alternative concentration measures, an alternative dependent variable, and we omit observations when the H-Statistic is in disequilibrium. We also test for bankspecific endogeneity. Further sensitivity tests examine sample selectivity. Our final checks employ bootstrapping to correct the standard errors of the H-Statistic and clustering of standard errors to allow for intra-group correlation at the country level.

- $\quad$ First, we utilize two alternative H-Statistics, distinguishing again between small and large banks. We calculate one H-Statistic using the ratio of interest revenue to total assets, instead of the ratio of total revenue to total assets, as a dependent variable (Molyneux et al., 1994). Subsequently, we compute an H-Statistic without the equity ratio as a control variable (see Section 3) to investigate if any remaining correlation between the equity ratio and the H-Statistic drives our findings.

- $\quad$ Second, we replace our H-statistic data by the H-Statistics computed by Claessens and Laeven (2004). This is a tough test since Claessens and Laeven (2004) do not discriminate between bank size, and calculate their competitiveness measure for the sampling period 1994-2001. However, since the regulatory environment has not undergone much change over time, we expect that the different sampling horizon will not markedly impact the inferences. The coefficient for the H-Statistic confirms this conjecture.

- $\quad$ Third, we replace the 3-bank concentration ratio by the Herfindahl-Hirschman index as an alternative measure of concentration. ${ }^{19}$ Unlike the 3-bank concentration ratio, this index takes all banks in the system into consideration. The Herfindahl-Hirschman index enters the equation with a negative sign, thus reiterating that there is an ambiguous relationship between concentration in banking systems and the level of capital held by individual banks. The H-Statistic remains positively and significantly associated with the capital ratio.

- $\quad$ Fourth, we replace the dependent variable, the capital ratio, with the ratio of equity to liabilities and find again that banks are more capitalized when competition increases. $^{20}$

\footnotetext{
${ }^{19}$ The Herfindahl-Hirschman index is the sum of the squared market shares. Formally, $H H I=\sum_{i=1}^{n} s_{i}^{2}$ where $s$ is the market share for bank $i, \ldots, n$. The HHI index ranges between $1 / \mathrm{n}$ and 1 (Bikker, 2004).

${ }^{20}$ The correlation between the capital ratio and leverage is 0.81 .
} 
- $\quad$ Fifth, we eliminate the bank-specific control variables to examine bank-specific endogeneity. Setup (6) confirms that this is not the case, because it does not change our main inferences about the relationship between competition and capital ratios.

- $\quad$ Sixth, we perform tests for sample selectivity. Switzerland is omitted to constrain the sample to EU banks in Setup (7). Switzerland, Denmark, Sweden and the United Kingdom are dropped from the sample in Setup (8) to only focus on banks operating in the Euro-currency area. In all specifications, the H-Statistic enters positively and significantly. Setup (9) omits H-Statistics computed with less than 20 observations, since Claessens and Laeven (2004) argue that 20 banks are necessary to obtain reasonable estimates for the H-Statistic. ${ }^{21}$ Using these alternative samples has no marked effect on our inferences and we conclude that our results are not subject to sample selectivity.

- $\quad$ Seventh, in Setup (10), we perform the long-term equilibrium test described in Section III.A and remove those bank-year observations for which the market fails to pass this test. ${ }^{22}$ Our result is not affected after dropping these observations. Setup (11) allows for clustering of the standard errors at the country level. Again, the main findings remain unchanged, suggesting that the fact that our regressions combine micro- and macro-level explanatory variables does not affect our inferences.

- $\quad$ Finally, we run robustness checks where we correct the standard errors of the HStatistic using a bootstrapping procedure with 1,000 replications. The results in Setups (11) and (12) reiterate our inferences about the positive and significant impact of the H-Statistic on capital ratios. ${ }^{23}$

\section{Conclusion}

This paper empirically analyses the nexus between banking competition, concentration, and capital ratios. We extend the existing literature in several ways. This research is to the best of our knowledge the first study to relate a direct measure of bank competition to capital ratios.

\footnotetext{
${ }^{21}$ This means dropping observations for all banks in Belgium, large banks in Denmark, and large banks in Luxembourg in 2003 and 2004, and all banks in the UK in 1999.

22 This means dropping observations for small Italian banks in 2002-2003, large Italian banks in 2003, small Swiss banks in 2000-2002 and 2004, small banks in Luxembourg in 2004, large banks in Luxembourg in 2000, and small banks in Sweden in 2001-2004.

${ }^{23}$ We also tested the effect of using additional country dummies and year dummies and ran tests, in which we examined the effect of macroeconomic volatility by including the standard deviation of GDP growth in the country. We further examined survivorship bias by restricting the analysis to institutions that remain in the sample during the whole period, excluded savings and cooperative banks to take into consideration that those banks are not strictly profit maximizing entities, and finally removed banks for which the capital ratio is either negative or equal to one. None of those tests changed our inferences. The results can be obtained upon request.
} 
Using bank-level data for ten European countries from 1999-2004, we find that banks hold higher capital buffers when operating in a more competitive environment. While the effect of competition is slightly reduced when banks operate in a country with a high level of economic development and when the banking industry is more concentrated, our results hold up to a broad set of robustness tests. Moreover, the effect of increasing competition on capital ratios is considerable: a 1 percent increase in the H-Statistic increases the capital ratio for the median bank in our sample from 5.6 percent to 5.9 percent. We find no consistent relationship between concentration and capital ratios. These results suggest the need for a reexamination of the positive link between concentration and banking stability reported in previous research on banking stability on the systemic level. Moreover, the independent effects arising from competition and concentration for capital ratios indicate that concentration is an inappropriate measure for competition in banking, and that regulatory policies concerning competition in banking based on concentration measures ought to be reevaluated.

In sum, our results offer empirical support for theoretical studies that propose a positive effect of competition on bank stability. The findings therefore bolster the view that competition and soundness tend to go hand in hand (even though this result does not necessarily mean that competitive banking systems will be free of failures). An interesting question for future research is what this means for efficiency: higher capital, while good for safety and soundness, may be a sign of lower efficiency. At the same time, competition is likely to force banks to operate close to the efficiency frontier. The overall impact of competition on efficiency is therefore an interesting topic for future empirical work.

Our findings have potential policy implications. While the traditional literature on this topic suggests that restrictions on competition can have a value in curtailing banks' reckless behavior, we do not find evidence that would justify such restrictions. On the contrary, our results indicate that competition encourages banks to increase capital ratios, even after adjusting for differences in risk-taking and a range of other variables. This paper thus adds to the growing body of evidence in favor of prudential frameworks that are "market friendly," i.e. consistent with free competition and a level playing field in banking. 
Table 1. H-Statistics

\begin{tabular}{|c|c|c|c|c|c|c|c|c|c|c|c|}
\hline Country & $\begin{array}{l}\text { Observations } \\
\text { (all banks) }\end{array}$ & $\begin{array}{l}\text { Observations } \\
\text { (small banks) }\end{array}$ & $\begin{array}{l}\text { Observations } \\
\text { (large banks) }\end{array}$ & $\begin{array}{l}\text { Average } \\
\text { number of } \\
\text { small banks } \\
\end{array}$ & $\begin{array}{l}\text { Average } \\
\text { number of } \\
\text { large banks } \\
\end{array}$ & $\begin{array}{l}\mathrm{H} 1 \\
\text { (small } \\
\text { banks) } \\
\end{array}$ & $\begin{array}{l}\mathrm{H} 1 \\
\text { (large } \\
\text { banks) } \\
\end{array}$ & $\begin{array}{l}\mathrm{H} 2 \\
\text { (small } \\
\text { banks) } \\
\end{array}$ & $\begin{array}{l}\mathrm{H} 2 \\
\text { (large } \\
\text { banks) } \\
\end{array}$ & HCL & $\begin{array}{l}\text { Average } \\
\text { concentration } \\
\text { ratio } \\
\end{array}$ \\
\hline Austria & 621 & 306 & 315 & 73 & 37 & 0.80 & 0.61 & 0.24 & 0.40 & 0.66 & 0.51 \\
\hline Belgium & 176 & 34 & 142 & 10 & 18 & -0.23 & 0.32 & 0.61 & 0.47 & 0.73 & 0.76 \\
\hline Denmark & 424 & 330 & 94 & 46 & 10 & 0.35 & 0.67 & 0.28 & 0.76 & 0.50 & 0.80 \\
\hline France & 1128 & 292 & 836 & 38 & 98 & 0.64 & 0.42 & 0.52 & 0.31 & 0.69 & 0.29 \\
\hline Germany & 10650 & 4486 & 6164 & 731 & 763 & 0.72 & 0.68 & 0.45 & 0.51 & 0.58 & 0.40 \\
\hline Italy & 2322 & 1182 & 1140 & 193 & 145 & 0.60 & 0.69 & 0.15 & 0.70 & 0.60 & 0.30 \\
\hline Luxembourg & 575 & 99 & 476 & 23 & 60 & 0.93 & 0.75 & 0.74 & 0.82 & 0.82 & 0.24 \\
\hline Sweden & 516 & 315 & 201 & 76 & $\mathrm{n} / \mathrm{a}$ & 0.57 & $\mathrm{n} / \mathrm{a}$ & 0.54 & $\mathrm{n} / \mathrm{a}$ & $\mathrm{n} / \mathrm{a}$ & 0.74 \\
\hline Switzerland & 1980 & 1177 & 803 & 189 & 48 & 0.73 & 0.79 & 0.27 & 0.68 & 0.67 & 0.83 \\
\hline $\begin{array}{l}\text { United } \\
\text { Kingdom }\end{array}$ & 390 & 94 & 296 & 21 & 22 & 0.75 & 0.51 & 0.61 & 0.11 & 0.74 & 0.39 \\
\hline
\end{tabular}

Note: H-Statistic (H1) is calculated with the total revenue as dependent variable; H-Statistic (H2) is calculated with interest revenue as dependent variable. HCL denotes the H-Statistics obtained from Claessens and Laeven (2004). The table reports averages for the H-Statistics (H1 and H2) and for the concentration ratio for the sampling period $1999-2004$. 
Table 2. Descriptive Statistics

\begin{tabular}{|c|c|c|c|c|c|c|}
\hline Variable & $\mathrm{N}$ & Mean & Median & Min & Max & S.D. \\
\hline Capital ratio & 15649 & 0.084 & 0.056 & -0.041 & 1.000 & 0.093 \\
\hline Leverage (inverse) & 15615 & 0.114 & 0.060 & -0.045 & 9.702 & 0.317 \\
\hline H-Statistic (H1) & 13157 & 0.657 & 0.655 & -0.23 & 0.987 & 0.168 \\
\hline H-Statistic (H2) & 13157 & 0.433 & 0.433 & 0.015 & 0.912 & 0.218 \\
\hline H-Statistic (H3) & 13157 & 0.690 & 0.707 & 0.020 & 0.992 & 0.170 \\
\hline H-Statistic (Claessens and Laeven) & 15145 & 0.612 & 0.580 & 0.500 & 0.820 & 0.059 \\
\hline Concentration & 18782 & 0.446 & 0.399 & 0.238 & 0.828 & 0.169 \\
\hline Herfindahl-Hirschman index & 15575 & 0.120 & 0.070 & 0.037 & 0.487 & 0.126 \\
\hline Banking freedom & 18782 & 2.467 & 3.000 & 1.000 & 3.000 & 0.754 \\
\hline Entry restrictions & 18782 & 7.313 & 7.000 & 6.000 & 8.000 & 0.579 \\
\hline Activity restrictions & 18782 & 7.353 & 7.000 & 5.000 & 10.000 & 1.196 \\
\hline Pretax profit/Total assets & 13187 & 0.008 & 0.005 & -0.435 & 0.777 & 0.024 \\
\hline Interbank ratio & 11661 & 1.260 & 0.683 & 0.000 & 9.964 & 1.662 \\
\hline Loan loss provisions/Net loans & 12186 & 0.001 & 0.000 & -0.068 & 0.515 & 0.013 \\
\hline Total assets, deflated (log) & 13243 & 12.962 & 12.889 & 7.242 & 19.231 & 1.402 \\
\hline Asset growth & 12127 & 0.0560 & 0.0289 & -0.3478 & 0.9696 & 0.1384 \\
\hline GDP growth & 18782 & 0.017 & 0.018 & -0.004 & 0.090 & 0.014 \\
\hline Inflation & 18782 & 0.011 & 0.009 & -0.007 & 0.042 & 0.010 \\
\hline Real interest rate & 16024 & 0.066 & 0.081 & 0.005 & 0.104 & 0.026 \\
\hline GDP per capita & 18782 & 24459.73 & 23332.33 & 17818.20 & 46659.27 & 5299.23 \\
\hline Market share & 15252 & 0.001 & 0.000 & 0.000 & 0.096 & 0.004 \\
\hline Non-performing loans/Total loans & 12213 & 0.046 & 0.047 & 0.003 & 0.078 & 0.015 \\
\hline Stock market cap/GDP & 18782 & 0.819 & 0.567 & 0.127 & 3.220 & 0.668 \\
\hline Credit growth & 11908 & 0.036 & 0.036 & -0.568 & 3.113 & 0.262 \\
\hline Life insurance penetration & 18782 & 0.026 & 0.024 & 0.008 & 0.064 & 0.013 \\
\hline Banks/Population (log) & 18782 & -4.559 & -4.513 & -5.551 & -3.366 & 0.361 \\
\hline Scandinavian legal origin & 18782 & 0.050 & 0.000 & 0.000 & 1.000 & 0.218 \\
\hline French legal origin & 18782 & 0.224 & 0.000 & 0.000 & 1.000 & 0.417 \\
\hline Property rights index & 18782 & 1.202 & 1.000 & 1.000 & 2.000 & 0.402 \\
\hline Government ownership & 18207 & 0.312 & 0.364 & 0.000 & 0.504 & 0.106 \\
\hline Foreign ownership & 16341 & 0.093 & 0.043 & 0.000 & 0.946 & 0.176 \\
\hline Moral hazard index & 18266 & 1.670 & 1.674 & 1.575 & 1.851 & 0.046 \\
\hline Capital regulatory index & 18207 & 5.910 & 6.000 & 2.000 & 8.000 & 0.880 \\
\hline Shareholder rights index & 18207 & 0.560 & 0.000 & 0.000 & 4.000 & 0.827 \\
\hline
\end{tabular}

Note: H-Statistic (H1) is calculated with the total revenue as dependent variable; H-Statistic (H2) is calculated as the H-Statistics calculated with interest revenue as dependent variable; H-Statistic (H3) is calculated with the total revenue as dependent variable but this equation does not contain the bank equity ratio as control variable. 
Table 3. Competition and Capital Ratio

\begin{tabular}{|c|c|c|c|c|c|c|c|}
\hline & $(1)$ & $(2)$ & (3) & $(4)$ & $(5)$ & (6) & $(7)$ \\
\hline Pretax profit/Total assets & $\begin{array}{l}1.0450 \\
(16.3060)^{* * *}\end{array}$ & $\begin{array}{l}0.9369 \\
(11.9135)^{* * *}\end{array}$ & $\begin{array}{l}0.6551 \\
(5.5637) * * *\end{array}$ & $\begin{array}{l}0.8483 \\
(7.2218) * * *\end{array}$ & $\begin{array}{l}0.9750 \\
(5.7573) * * *\end{array}$ & $\begin{array}{l}1.3263 \\
(2.4190)^{* *}\end{array}$ & $\begin{array}{l}1.9638 \\
(3.4065) * * *\end{array}$ \\
\hline Interbank ratio & $\begin{array}{l}0.0277 \\
(6.2004)^{* * *}\end{array}$ & $\begin{array}{l}0.0422 \\
(7.1180)^{* * *}\end{array}$ & $\begin{array}{l}0.0557 \\
(5.6249) * * *\end{array}$ & $\begin{array}{l}0.0654 \\
(6.4790) * * *\end{array}$ & $\begin{array}{l}0.0893 \\
(7.0704)^{* * *}\end{array}$ & $\begin{array}{l}-0.0283 \\
(0.5217)\end{array}$ & $\begin{array}{l}-0.0594 \\
(1.0740)\end{array}$ \\
\hline Loan loss provisions/Loans & $\begin{array}{l}0.2858 \\
(4.7079) * * *\end{array}$ & $\begin{array}{l}0.3254 \\
(4.4908) * * *\end{array}$ & $\begin{array}{l}0.1920 \\
(1.4377)\end{array}$ & $\begin{array}{l}0.3402 \\
(3.2675) * * *\end{array}$ & $\begin{array}{l}0.3951 \\
(3.1164) * * *\end{array}$ & $\begin{array}{l}-0.3441 \\
(0.6671)\end{array}$ & $\begin{array}{l}-0.3613 \\
(0.7791)\end{array}$ \\
\hline Total assets, deflated & $\begin{array}{l}-0.0062 \\
(6.9582)^{* * *}\end{array}$ & $\begin{array}{l}-0.0024 \\
(1.8901)^{*}\end{array}$ & $\begin{array}{l}-0.0087 \\
(3.6489)^{* * *}\end{array}$ & $\begin{array}{l}-0.0167 \\
(0.9023)\end{array}$ & $\begin{array}{l}-0.0101 \\
(0.4514)\end{array}$ & $\begin{array}{l}0.2654 \\
(2.1619)^{* *}\end{array}$ & $\begin{array}{l}0.5761 \\
(2.9316)^{* * *}\end{array}$ \\
\hline GDP growth & $\begin{array}{l}0.9759 \\
(6.8792)^{* * *}\end{array}$ & $\begin{array}{l}0.8477 \\
(4.9837) * * *\end{array}$ & $\begin{array}{l}1.7459 \\
(5.8983) * * *\end{array}$ & $\begin{array}{l}1.8286 \\
(5.0010) * * *\end{array}$ & $\begin{array}{l}1.4224 \\
(3.3248) * * *\end{array}$ & $\begin{array}{l}16.9506 \\
(3.3051)^{* * *}\end{array}$ & $\begin{array}{l}15.7177 \\
(3.4826)^{* * *}\end{array}$ \\
\hline Inflation & $\begin{array}{l}0.9737 \\
(4.6814) * * *\end{array}$ & $\begin{array}{l}0.9839 \\
(3.9833) * * *\end{array}$ & $\begin{array}{l}2.7029 \\
(5.3316) * * *\end{array}$ & $\begin{array}{l}2.9439 \\
(4.5024) * * *\end{array}$ & $\begin{array}{l}2.5527 \\
(3.3408) * * *\end{array}$ & $\begin{array}{l}24.0529 \\
(3.2550) * * *\end{array}$ & $\begin{array}{l}23.4934 \\
(3.4385) * * *\end{array}$ \\
\hline Real interest rate & $\begin{array}{l}-0.1289 \\
(1.4551)\end{array}$ & $\begin{array}{l}0.3217 \\
(2.4069) * *\end{array}$ & $\begin{array}{l}0.4313 \\
(1.6418)\end{array}$ & $\begin{array}{l}1.2346 \\
(2.9599) * * *\end{array}$ & $\begin{array}{l}1.8202 \\
(3.4845)^{* * *}\end{array}$ & $\begin{array}{l}-5.9826 \\
(2.0084)^{* *}\end{array}$ & $\begin{array}{l}-11.0899 \\
(2.6814)^{* * *}\end{array}$ \\
\hline H-Statistic (Total revenue) & $\begin{array}{l}0.1226 \\
(5.4752) * * *\end{array}$ & $\begin{array}{l}0.0882 \\
(3.2267) * * *\end{array}$ & $\begin{array}{l}0.5601 \\
(5.8730)^{* * *}\end{array}$ & $\begin{array}{l}0.3229 \\
(4.4870) * * *\end{array}$ & $\begin{array}{l}0.3115 \\
(3.7037) * * *\end{array}$ & $\begin{array}{l}2.7466 \\
(3.2580) * * *\end{array}$ & $\begin{array}{l}2.7132 \\
(3.4396) * * *\end{array}$ \\
\hline Concentration & & $\begin{array}{l}0.0590 \\
(5.4645) * * *\end{array}$ & $\begin{array}{l}-0.3778 \\
(4.3772) * * *\end{array}$ & $\begin{array}{l}-0.2731 \\
(1.5860)\end{array}$ & $\begin{array}{l}-0.2212 \\
(1.0355)\end{array}$ & $\begin{array}{l}-0.9809 \\
(1.2194)\end{array}$ & $\begin{array}{l}-0.5145 \\
(0.7536)\end{array}$ \\
\hline GDP per capita & & & $\begin{array}{l}0.0000 \\
(4.3014) * * *\end{array}$ & $\begin{array}{l}0.0000 \\
(2.3130)^{* *}\end{array}$ & $\begin{array}{l}0.0000 \\
(1.7529)^{*}\end{array}$ & $\begin{array}{l}0.0001 \\
(2.3670)^{* *}\end{array}$ & $\begin{array}{l}0.0001 \\
(2.4749)^{* *}\end{array}$ \\
\hline Market share (log) & & & & $\begin{array}{l}0.0151 \\
(0.7998)\end{array}$ & $\begin{array}{l}0.0132 \\
(0.5795)\end{array}$ & $\begin{array}{l}-0.3366 \\
(2.3819)^{* *}\end{array}$ & $\begin{array}{l}-0.6549 \\
(2.9850) * * *\end{array}$ \\
\hline Asset growth & & & & & $\begin{array}{l}-0.0134 \\
(1.0700)\end{array}$ & & \\
\hline GDP per capita $*$ H-Statistic & & & & & & $\begin{array}{l}-0.0005 \\
(3.1116) * * *\end{array}$ & \\
\hline H-Statistic * Concentration & & & & & & & $\begin{array}{l}-11.0176 \\
(3.2475)^{* * *}\end{array}$ \\
\hline Observations & 8584 & 8584 & 8584 & 8583 & 8456 & 8583 & 8583 \\
\hline Number of banks & 2631 & 2631 & 2631 & 2631 & 2618 & 2631 & 2631 \\
\hline Wald $\chi 2$ & $1688.10 * * *$ & $1226.98 * * *$ & $290.52 * * *$ & $613.40 * * *$ & $426.41 * * *$ & $40.23 * * *$ & $50.03 * * *$ \\
\hline
\end{tabular}

Note: Constant term included but not reported. Absolute value of z statistics in parentheses. H-Statistic, concentration and market share instrumented using entry restrictions, banking freedom and activity restrictions. Interbank ratio instrumented using pretax profit/total assets, cost/income ratio, and total assets $(\mathrm{log})$. Interaction terms use centered variables to reduce collinearity. * significant at $10 \%$; ** significant at $5 \%$; *** significant at $1 \%$. 
Table 4. Quantifying the Effect of Increases in the H-Statistic on the Capital Ratio

\begin{tabular}{|c|c|c|c|c|c|c|}
\hline Percentile & $\begin{array}{l}1) \\
25 \text { th } \\
\end{array}$ & $\begin{array}{l}\text { Increase in } \\
\text { percent }\end{array}$ & $\begin{array}{l}(2) \\
50 \text { th }\end{array}$ & $\begin{array}{l}\text { Increase in } \\
\text { percent }\end{array}$ & $\begin{array}{l}3) \\
75 \text { th }\end{array}$ & $\begin{array}{l}\text { Increase in } \\
\text { percent }\end{array}$ \\
\hline $\begin{array}{l}\text { Capital ratio } \\
\text { (all banks) }\end{array}$ & 0.0445 & & 0.0559 & & 0.0872 & \\
\hline $\begin{array}{l}\text { Effect increases } \\
\text { capital ratio to }\end{array}$ & 0.0477 & $7.2 \%$ & 0.0591 & $5.7 \%$ & 0.0904 & $7.8 \%$ \\
\hline $\begin{array}{l}\text { Capital ratio } \\
\text { (small banks) }\end{array}$ & 0.0492 & & 0.0635 & & 0.1167 & \\
\hline $\begin{array}{l}\text { Effect increases } \\
\text { capital ratio to }\end{array}$ & 0.0524 & $6.1 \%$ & 0.0667 & $5.0 \%$ & 0.1199 & $2.7 \%$ \\
\hline $\begin{array}{l}\text { Capital ratio } \\
\text { (large banks) }\end{array}$ & 0.0413 & & 0.0502 & & 0.0647 & \\
\hline $\begin{array}{l}\text { Effect increases } \\
\text { capital ratio to }\end{array}$ & 0.0445 & $7.7 \%$ & 0.0534 & $6.4 \%$ & 0.0679 & $4.9 \%$ \\
\hline
\end{tabular}

Note: Effect of a one percent (0.01) increase in the H-Statistic (0.0032) on the capital ratio, evaluated at the 25th, 50th, and 75th percentile of the distribution of the capital ratio. 
Table 5. Competition, Capital Ratio, and the Wider Financial System

\begin{tabular}{|c|c|c|c|c|c|c|}
\hline & $(1)$ & $(2)$ & (3) & $(4)$ & $(5)$ & $(6)$ \\
\hline Pretax profit/Total assets & $\begin{array}{l}1.1181 \\
(3.5276)^{* * *}\end{array}$ & $\begin{array}{l}1.9348 \\
(4.3509)^{* * *}\end{array}$ & $\begin{array}{l}0.4878 \\
(2.1526) * *\end{array}$ & $\begin{array}{l}0.6314 \\
(4.3818)^{* * *}\end{array}$ & $\begin{array}{l}0.5450 \\
(3.6573)^{* * *}\end{array}$ & $\begin{array}{l}0.8708 \\
(3.9039) * * *\end{array}$ \\
\hline Interbank ratio & $\begin{array}{l}-0.0017 \\
(0.0590)\end{array}$ & $\begin{array}{l}-0.0260 \\
(0.7016)\end{array}$ & $\begin{array}{l}0.0977 \\
(5.0484) * * *\end{array}$ & $\begin{array}{l}0.0843 \\
(6.5925)^{* * *}\end{array}$ & $\begin{array}{l}0.0924 \\
(5.3146)^{* * *}\end{array}$ & $\begin{array}{l}0.0454 \\
(2.3036)^{* *}\end{array}$ \\
\hline Loan loss provisions/Net loans & $\begin{array}{l}0.0606 \\
(0.2547)\end{array}$ & $\begin{array}{l}-0.0767 \\
(0.2671)\end{array}$ & $\begin{array}{l}0.3743 \\
(1.9739)^{* *}\end{array}$ & $\begin{array}{l}0.4033 \\
(3.2505)^{* * *}\end{array}$ & $\begin{array}{l}0.3355 \\
(2.2998)^{* *}\end{array}$ & $\begin{array}{l}0.1713 \\
(0.8503)\end{array}$ \\
\hline Total assets, deflated & $\begin{array}{l}0.3899 \\
(3.0204)^{* * *}\end{array}$ & $\begin{array}{l}0.1735 \\
(2.3120)^{* *}\end{array}$ & $\begin{array}{l}-0.4216 \\
(4.7745)^{* * *}\end{array}$ & $\begin{array}{l}-0.1796 \\
(5.6523)^{* * *}\end{array}$ & $\begin{array}{l}-0.0488 \\
(1.7096)^{*}\end{array}$ & $\begin{array}{l}-0.3405 \\
(4.1188)^{* * *}\end{array}$ \\
\hline GDP growth & $\begin{array}{l}6.5287 \\
(5.2454)^{* * *}\end{array}$ & $\begin{array}{l}16.9497 \\
(3.5043)^{* * *}\end{array}$ & $\begin{array}{l}-0.5836 \\
(1.3651)\end{array}$ & $\begin{array}{l}0.3039 \\
(0.8111)\end{array}$ & $\begin{array}{l}1.4422 \\
(3.9478)^{* * *}\end{array}$ & $\begin{array}{l}3.5998 \\
(5.2851)^{* * *}\end{array}$ \\
\hline Inflation & $\begin{array}{l}6.8096 \\
(4.7884)^{* * *}\end{array}$ & $\begin{array}{l}7.0039 \\
(3.5712)^{* * *}\end{array}$ & $\begin{array}{l}5.7209 \\
(5.0343)^{* * *}\end{array}$ & $\begin{array}{l}1.5647 \\
(2.3395)^{* *}\end{array}$ & $\begin{array}{l}2.4267 \\
(3.5179)^{* * *}\end{array}$ & $\begin{array}{l}8.0913 \\
(5.1336)^{* * *}\end{array}$ \\
\hline Real interest rate & $\begin{array}{l}-8.7724 \\
(3.2204)^{* * *}\end{array}$ & $\begin{array}{l}-9.9901 \\
(2.7858)^{* * *}\end{array}$ & $\begin{array}{l}11.0690 \\
(5.1455)^{* * *}\end{array}$ & $\begin{array}{l}3.7725 \\
(5.6512)^{* * *}\end{array}$ & $\begin{array}{l}2.0681 \\
(2.8993)^{* * *}\end{array}$ & $\begin{array}{l}6.8166 \\
(4.5013)^{* * *}\end{array}$ \\
\hline GDP per capita & $\begin{array}{l}-0.0001 \\
(2.5246)^{* *}\end{array}$ & $\begin{array}{l}0.0001 \\
(3.1552)^{* * *}\end{array}$ & $\begin{array}{l}0.0001 \\
(4.5478) * * *\end{array}$ & $\begin{array}{l}0.0000 \\
(1.3707)\end{array}$ & $\begin{array}{l}0.0000 \\
(2.9571)^{* * *}\end{array}$ & $\begin{array}{l}0.0001 \\
(4.4106) * * *\end{array}$ \\
\hline Market share (log) & $\begin{array}{l}-0.4043 \\
(3.0434)^{* * *}\end{array}$ & $\begin{array}{l}-0.2111 \\
(2.4847)^{* *}\end{array}$ & $\begin{array}{l}0.4222 \\
(4.7483)^{* * *}\end{array}$ & $\begin{array}{l}0.1834 \\
(5.6277)^{* * *}\end{array}$ & $\begin{array}{l}0.0507 \\
(1.7120)^{*}\end{array}$ & $\begin{array}{l}0.3253 \\
(4.0547)^{* * *}\end{array}$ \\
\hline Concentration & $\begin{array}{l}0.7991 \\
(1.4274)\end{array}$ & $\begin{array}{l}-0.1386 \\
(0.3267)\end{array}$ & $\begin{array}{l}-3.8455 \\
(4.7899) * * *\end{array}$ & $\begin{array}{l}-0.8408 \\
(3.7898)^{* * *}\end{array}$ & $\begin{array}{l}-0.7413 \\
(2.6096)^{* * *}\end{array}$ & $\begin{array}{l}-2.6320 \\
(4.1948) * * *\end{array}$ \\
\hline H-Statistic (Total revenue) & $\begin{array}{l}1.9403 \\
(4.6793)^{* * *}\end{array}$ & $\begin{array}{l}1.9110 \\
(3.5800)^{* * *}\end{array}$ & $\begin{array}{l}0.9734 \\
(5.3423)^{* * *}\end{array}$ & $\begin{array}{l}0.2883 \\
(3.7965)^{* * *}\end{array}$ & $\begin{array}{l}0.4171 \\
(4.1950)^{* * *}\end{array}$ & $\begin{array}{l}1.4446 \\
(5.0153)^{* * *}\end{array}$ \\
\hline Non-performing loans/Banking system loans & $\begin{array}{l}-10.5008 \\
(4.6449)^{* * *}\end{array}$ & & & & & \\
\hline Stock market capitalization/GDP & & $\begin{array}{l}-0.5453 \\
(3.2619) * * *\end{array}$ & & & & \\
\hline Size of banking sector relative to stock market & & & $\begin{array}{l}-0.1687 \\
(5.2094)^{* * *}\end{array}$ & & & \\
\hline Life insurance penetration & & & & $\begin{array}{l}5.7209 \\
(5.8493)^{* * *}\end{array}$ & & \\
\hline Credit growth & & & & & $\begin{array}{l}-0.0230 \\
(2.1549)^{* *}\end{array}$ & \\
\hline Number of banks/population (log) & & & & & & $\begin{array}{l}-0.4156 \\
(4.3627)^{* * *}\end{array}$ \\
\hline Observations & 6278 & 8583 & 8583 & 8583 & 8398 & 8583 \\
\hline Number of banks & 2380 & 2631 & 2631 & 2631 & 2612 & 2631 \\
\hline Wald $\chi 2$ & $107.25 * * *$ & $111.73 * * *$ & $210.35 * * *$ & $457.44 * * *$ & $257.57 * * *$ & $189.99 * * *$ \\
\hline
\end{tabular}

Note: Absolute value of $\mathrm{z}$ statistics in parentheses. Setup (1) controls for the ratio of non-performing loans to total loans in the system and Setup (2) controls for the size of the stock market. We introduce controls for the size of the banking sector relative to the stock market in Setup (3) and consider the effect of life insurers in Setup (4). Setup (5) controls for credit growth and Setup (6) for the number of banks in the system. Constant term included but not reported. HStatistic, concentration and market share instrumented using banking freedom, entry restrictions, and activity restrictions. Interbank ratio instrumented using pretax profit/total assets, cost/income ratio, and total assets $(\log ) .{ }^{*}$ significant at $10 \%$; ** significant at 5\%; *** significant at $1 \%$. 
Table 6. Competition, Capital Ratio, and the Regulatory and Institutional Environment

\begin{tabular}{|c|c|c|c|c|c|c|c|}
\hline & $(1)$ & $(2)$ & (3) & (4) & (5) & (6) & (7) \\
\hline Pretax profit/Total assets & $\begin{array}{l}0.9718 \\
(10.4981)^{* * *}\end{array}$ & $\begin{array}{l}0.8343 \\
(6.5430)^{* * *}\end{array}$ & $\begin{array}{l}1.0328 \\
(14.2165)^{* * *}\end{array}$ & $\begin{array}{l}0.9753 \\
(8.2132)^{* * *}\end{array}$ & $\begin{array}{l}0.9632 \\
(7.5533)^{* * *}\end{array}$ & $\begin{array}{l}0.8775 \\
(12.1585)^{* * *}\end{array}$ & $\begin{array}{l}1.3465 \\
(5.2328)^{* * *}\end{array}$ \\
\hline Interbank ratio & $\begin{array}{l}0.0402 \\
(4.5236)^{* * * *}\end{array}$ & $\begin{array}{l}0.0693 \\
(6.2495)^{* * *}\end{array}$ & $\begin{array}{l}0.0261 \\
(3.7873)^{* * *}\end{array}$ & $\begin{array}{l}0.0589 \\
(6.4015)^{* * *}\end{array}$ & $\begin{array}{l}0.0444 \\
(3.8621)^{* * *}\end{array}$ & $\begin{array}{l}0.0322 \\
(3.9832)^{* * *}\end{array}$ & $\begin{array}{l}-0.0437 \\
(1.6889)^{*}\end{array}$ \\
\hline Loan loss provisions/Net loans & $\begin{array}{l}0.2860 \\
(3.5987)^{* * *}\end{array}$ & $\begin{array}{l}0.3417 \\
(3.0252)^{* * *}\end{array}$ & $\begin{array}{l}0.2927 \\
(4.8765)^{* * *}\end{array}$ & $\begin{array}{l}0.2870 \\
(2.6468) * * *\end{array}$ & $\begin{array}{l}0.2480 \\
(2.1609) * *\end{array}$ & $\begin{array}{l}0.3039 \\
(4.8907)^{* * *}\end{array}$ & $\begin{array}{l}-0.0518 \\
(0.2272)\end{array}$ \\
\hline Total assets, deflated & $\begin{array}{l}-0.0741 \\
(5.8197)^{* * *}\end{array}$ & $\begin{array}{l}0.0444 \\
(2.3673)^{* *}\end{array}$ & $\begin{array}{l}0.0267 \\
(1.7297)^{*}\end{array}$ & $\begin{array}{l}-0.0128 \\
(0.6812)\end{array}$ & $\begin{array}{l}-0.1225 \\
(5.1111)^{* * *}\end{array}$ & $\begin{array}{l}-0.0801 \\
(4.5212)^{* * *}\end{array}$ & $\begin{array}{l}-0.3960 \\
(4.8868) * * *\end{array}$ \\
\hline GDP growth & $\begin{array}{l}0.1093 \\
(0.6318)\end{array}$ & $\begin{array}{l}2.3098 \\
(4.9555)^{* * *}\end{array}$ & $\begin{array}{l}0.5211 \\
(4.3985)^{* * *}\end{array}$ & $\begin{array}{l}2.3830 \\
(5.8253)^{* * *}\end{array}$ & $\begin{array}{l}2.0219 \\
(5.3936)^{* * *}\end{array}$ & $\begin{array}{l}0.2642 \\
(1.5116)\end{array}$ & $\begin{array}{l}0.0628 \\
(0.1350)\end{array}$ \\
\hline Inflation & $\begin{array}{l}1.4733 \\
(5.2536)^{* * *}\end{array}$ & $\begin{array}{l}3.0425 \\
(4.6021)^{* * *}\end{array}$ & $\begin{array}{l}-0.0045 \\
(0.0175)\end{array}$ & $\begin{array}{l}3.3346 \\
(5.0566) * * *\end{array}$ & $\begin{array}{l}4.7506 \\
(6.0570)^{* * *}\end{array}$ & $\begin{array}{l}0.1629 \\
(0.5683)\end{array}$ & $\begin{array}{l}6.1758 \\
(4.5295) * * *\end{array}$ \\
\hline Real interest rate & $\begin{array}{l}2.6328 \\
(6.7113)^{* * *}\end{array}$ & $\begin{array}{l}-0.5026 \\
(1.3129)\end{array}$ & $\begin{array}{l}-0.8263 \\
(1.7019)^{*}\end{array}$ & $\begin{array}{l}0.4802 \\
(1.3769)\end{array}$ & $\begin{array}{l}3.4145 \\
(6.4768)^{* * *}\end{array}$ & $\begin{array}{l}1.2705 \\
(5.3133)^{* * *}\end{array}$ & $\begin{array}{l}7.4816 \\
(4.8960) * * *\end{array}$ \\
\hline GDP per capita & $\begin{array}{l}0.0000 \\
(7.5086)^{* * *}\end{array}$ & $\begin{array}{l}-0.0000 \\
(3.0735)^{* * *}\end{array}$ & $\begin{array}{l}-0.0000 \\
(1.8542)^{*}\end{array}$ & $\begin{array}{l}0.0000 \\
(3.2850)^{* * *}\end{array}$ & $\begin{array}{l}0.0000 \\
(4.6799) * * *\end{array}$ & $\begin{array}{l}0.0000 \\
(0.7741)\end{array}$ & $\begin{array}{l}0.0000 \\
(1.0134)\end{array}$ \\
\hline Market share (log) & $\begin{array}{l}0.0676 \\
(5.0898) * * *\end{array}$ & $\begin{array}{l}-0.0465 \\
(2.4200)^{* *}\end{array}$ & $\begin{array}{l}-0.0325 \\
(1.9346)^{*}\end{array}$ & $\begin{array}{l}0.0049 \\
(0.2552)\end{array}$ & $\begin{array}{l}0.1133 \\
(4.9572)^{* * *}\end{array}$ & $\begin{array}{l}0.0754 \\
(4.6273)^{* * *}\end{array}$ & $\begin{array}{l}0.3581 \\
(4.7453)^{* * *}\end{array}$ \\
\hline Concentration & $\begin{array}{l}-0.4875 \\
(6.5130)^{* * *}\end{array}$ & $\begin{array}{l}0.1445 \\
(1.1351)\end{array}$ & $\begin{array}{l}0.2454 \\
(2.4767)^{* *}\end{array}$ & $\begin{array}{l}-0.3894 \\
(2.1615)^{* *}\end{array}$ & $\begin{array}{l}-0.9296 \\
(4.6184)^{* * *}\end{array}$ & $\begin{array}{l}-0.1977 \\
(1.9075)^{*}\end{array}$ & $\begin{array}{l}-2.2415 \\
(4.1809)^{* * *}\end{array}$ \\
\hline H-Statistic (Total revenue) & $\begin{array}{l}0.3075 \\
(6.5248)^{* * *}\end{array}$ & $\begin{array}{l}0.4209 \\
(4.5206)^{* * *}\end{array}$ & $\begin{array}{l}0.0465 \\
(1.2622)\end{array}$ & $\begin{array}{l}0.5191 \\
(5.6535) * * *\end{array}$ & $\begin{array}{l}0.6941 \\
(6.6125)^{* * *}\end{array}$ & $\begin{array}{l}0.1213 \\
(3.4282)^{* * *}\end{array}$ & $\begin{array}{l}1.6806 \\
(5.2521)^{* * *}\end{array}$ \\
\hline French legal origin & $\begin{array}{l}0.2403 \\
(8.3122)^{* * *}\end{array}$ & & & & & & \\
\hline Scandinavian legal origin & $\begin{array}{l}0.0519 \\
(1.9790)^{* *}\end{array}$ & & & & & & \\
\hline British legal origin & $\begin{array}{l}0.1120 \\
(6.6894)^{* * *}\end{array}$ & & & & & & \\
\hline Rule of law & & $\begin{array}{l}0.2591 \\
(3.7365)^{* * *}\end{array}$ & & & & & \\
\hline Moral hazard index & & & $\begin{array}{l}0.2964 \\
(1.9700)^{* *}\end{array}$ & & & & \\
\hline Capital regulatory index & & & & $\begin{array}{l}0.0624 \\
(6.4898) * * *\end{array}$ & & & \\
\hline Shareholder rights index & & & & & $\begin{array}{l}0.0606 \\
(5.6221)^{* * *}\end{array}$ & & \\
\hline Foreign ownership & & & & & & $\begin{array}{l}0.3554 \\
(4.9906)^{* * *}\end{array}$ & \\
\hline Government ownership & & & & & & & $\begin{array}{l}-2.7917 \\
(5.3774)^{* * *}\end{array}$ \\
\hline Observations & 8583 & 8583 & 8501 & 8583 & 8583 & 7830 & 8583 \\
\hline Number of banks & 2631 & 2631 & 2590 & 2631 & 2631 & 2403 & 2631 \\
\hline Wald $\chi^{2}$ & $1152.62 * * *$ & $524.81^{* * *}$ & $1839.40 * * *$ & $578.78 * * *$ & $560.08 * * *$ & $1578.79 * * *$ & $170.08^{* * *}$ \\
\hline
\end{tabular}

Note: Absolute value of z statistics in parentheses. Constant term included but not reported. Setup (1) controls for legal origin and Setup (2) controls for rule of law. A control variable for deposit insurance design features is included in Setup (3) and Setup (4) includes a capital regulatory index. We control for shareholder rights in Setup (5) and test ownership in Setup (6) and Setup (7). H-Statistic, concentration and market share instrumented using banking freedom, entry restrictions, and activity restrictions. Interbank ratio instrumented using pretax profit/total assets, cost/income ratio, and total assets (log).* significant at $10 \%$; $* *$ significant at $5 \%$; *** significant at $1 \%$. 
Table 7. Further Robustness Checks

\begin{tabular}{|c|c|c|c|c|c|c|c|c|c|c|c|c|}
\hline & $(1)$ & $(2)$ & $(3)$ & $(4)$ & $(5)$ & $(6)$ & $(7)$ & $(8)$ & $(9)$ & $(10)$ & $(11)$ & $(12)$ \\
\hline Pretax profit/Total assets & $\begin{array}{l}-0.3324 \\
(0.8656)\end{array}$ & $\begin{array}{l}0.8734 \\
(8.3015) \\
* * *\end{array}$ & $\begin{array}{l}-0.6195 \\
(1.5491)\end{array}$ & $\begin{array}{l}0.5748 \\
(2.7085) \\
* * *\end{array}$ & $\begin{array}{l}1.5251 \\
(4.9010) \\
* * *\end{array}$ & & $\begin{array}{l}0.6580 \\
(1.6415)\end{array}$ & $\begin{array}{l}0.9038 \\
(2.8353) \\
* * *\end{array}$ & $\begin{array}{l}0.7469 \\
(5.6189) \\
* * *\end{array}$ & $\begin{array}{l}1.2537 \\
(17.6799 \\
)^{* * *}\end{array}$ & $\begin{array}{l}0.3305 \\
(0.8070)\end{array}$ & $\begin{array}{l}0.8905 \\
(6.4647) \\
* * *\end{array}$ \\
\hline Interbank ratio & $\begin{array}{l}0.0850 \\
(3.8972) \\
* * *\end{array}$ & $\begin{array}{l}0.0603 \\
(6.4377) \\
* * *\end{array}$ & $\begin{array}{l}0.1237 \\
(3.7910) \\
* * *\end{array}$ & $\begin{array}{l}0.1010 \\
(4.5937) \\
* * *\end{array}$ & $\begin{array}{l}0.1588 \\
(5.8882) \\
* * *\end{array}$ & & $\begin{array}{l}-0.0079 \\
(0.2684)\end{array}$ & $\begin{array}{l}-0.0264 \\
(1.0015)\end{array}$ & $\begin{array}{l}0.0777 \\
(6.5634) \\
* * *\end{array}$ & $\begin{array}{l}0.0226 \\
(3.7156) \\
* * *\end{array}$ & $\begin{array}{l}0.0080 \\
(0.0917)\end{array}$ & $\begin{array}{l}0.0547 \\
(5.1930) \\
* * *\end{array}$ \\
\hline $\begin{array}{l}\text { Loan loss provisions/Net } \\
\text { loans }\end{array}$ & $\begin{array}{l}0.0788 \\
(0.3198)\end{array}$ & $\begin{array}{l}0.3469 \\
(3.7228) \\
* * *\end{array}$ & $\begin{array}{l}0.4401 \\
(1.2412)\end{array}$ & $\begin{array}{l}0.4422 \\
(2.7882) \\
* * *\end{array}$ & $\begin{array}{l}0.5612 \\
(2.0382) \\
* *\end{array}$ & & $\begin{array}{l}-0.0629 \\
(0.1948)\end{array}$ & $\begin{array}{l}-0.0946 \\
(0.3784)\end{array}$ & $\begin{array}{l}0.3666 \\
(3.1545) \\
* * *\end{array}$ & $\begin{array}{l}0.2774 \\
(5.4202) \\
* * *\end{array}$ & $\begin{array}{l}-0.3350 \\
(1.0660)\end{array}$ & $\begin{array}{l}0.2677 \\
(2.6278) \\
* * *\end{array}$ \\
\hline Total assets, deflated & $\begin{array}{l}0.1867 \\
(3.4449) \\
* * *\end{array}$ & $\begin{array}{l}-0.0084 \\
(0.5063)\end{array}$ & $\begin{array}{l}-1.7912 \\
(4.1070) \\
* * *\end{array}$ & $\begin{array}{l}-0.1494 \\
(2.2427) \\
* *\end{array}$ & $\begin{array}{l}-0.0875 \\
(1.7882) \\
*\end{array}$ & & $\begin{array}{l}-0.1585 \\
(2.2300) \\
* *\end{array}$ & $\begin{array}{l}-0.7316 \\
(3.7985) \\
* * *\end{array}$ & $\begin{array}{l}-0.0742 \\
(2.7764) \\
* * *\end{array}$ & $\begin{array}{l}0.0290 \\
(3.6349) \\
* * *\end{array}$ & $\begin{array}{l}-0.0095 \\
(0.0355)\end{array}$ & $\begin{array}{l}-0.0657 \\
(0.7747)\end{array}$ \\
\hline GDP growth & $\begin{array}{l}-0.0194 \\
(0.0396)\end{array}$ & $\begin{array}{l}1.1432 \\
(4.3209) \\
* * *\end{array}$ & $\begin{array}{l}-7.7387 \\
(3.8735) \\
* * *\end{array}$ & $\begin{array}{l}1.6270 \\
(3.4036) \\
* * *\end{array}$ & $\begin{array}{l}4.6514 \\
(4.7906) \\
* * *\end{array}$ & $\begin{array}{l}0.3164 \\
(3.6471) \\
* * *\end{array}$ & $\begin{array}{l}7.2408 \\
(3.2874) \\
* * *\end{array}$ & $\begin{array}{l}13.2002 \\
(4.2380) \\
* * *\end{array}$ & $\begin{array}{l}1.3689 \\
(4.2135) \\
* * *\end{array}$ & $\begin{array}{l}0.5663 \\
(3.3238) \\
* * *\end{array}$ & $\begin{array}{l}0.8609 \\
(0.7089)\end{array}$ & $\begin{array}{l}2.9044 \\
(4.2646) \\
* * *\end{array}$ \\
\hline Inflation & $\begin{array}{l}4.4619 \\
(3.8678) \\
* * *\end{array}$ & $\begin{array}{l}2.0377 \\
(3.7159) \\
* * *\end{array}$ & $\begin{array}{l}10.9719 \\
(4.0339) \\
* * *\end{array}$ & $\begin{array}{l}-2.8597 \\
(1.2423)\end{array}$ & $\begin{array}{l}8.0795 \\
(4.6449) \\
* * *\end{array}$ & $\begin{array}{l}-0.0557 \\
(0.3883)\end{array}$ & $\begin{array}{l}-0.2744 \\
(0.1648)\end{array}$ & $\begin{array}{l}-17.1064 \\
(4.6153) \\
* * *\end{array}$ & $\begin{array}{l}2.6756 \\
(4.3508) \\
* * *\end{array}$ & $\begin{array}{l}0.4882 \\
(1.5846)\end{array}$ & $\begin{array}{l}0.4164 \\
(0.1061)\end{array}$ & $\begin{array}{l}4.6400 \\
(3.7587) \\
* * *\end{array}$ \\
\hline Real interest rate & $\begin{array}{l}-2.5844 \\
(2.7698) \\
* * *\end{array}$ & $\begin{array}{l}0.8333 \\
(2.2847) \\
* *\end{array}$ & $\begin{array}{l}43.2282 \\
(4.1073) \\
* * *\end{array}$ & $\begin{array}{l}-0.4031 \\
(0.7360)\end{array}$ & $\begin{array}{l}4.3853 \\
(3.9420) \\
* * *\end{array}$ & $\begin{array}{l}-0.8255 \\
(11.1004 \\
)^{* * *}\end{array}$ & $\begin{array}{l}-8.8471 \\
(3.4759) \\
* * *\end{array}$ & $\begin{array}{l}-22.0767 \\
(4.8145) \\
* * *\end{array}$ & $\begin{array}{l}2.2307 \\
(3.9760) \\
* * *\end{array}$ & $\begin{array}{l}-0.7255 \\
(3.2076) \\
* * *\end{array}$ & $\begin{array}{l}-2.4370 \\
(0.3653)\end{array}$ & $\begin{array}{l}1.6413 \\
(2.2980) \\
* *\end{array}$ \\
\hline GDP per capita & $\begin{array}{l}-0.0000 \\
(2.5704) \\
* *\end{array}$ & $\begin{array}{l}0.0000 \\
(1.4845)\end{array}$ & $\begin{array}{l}0.0001 \\
(3.7172) \\
* * *\end{array}$ & $\begin{array}{l}0.0001 \\
(2.6060) \\
* * *\end{array}$ & $\begin{array}{l}0.0001 \\
(3.7255) \\
* * *\end{array}$ & $\begin{array}{l}-0.0000 \\
(4.7200) \\
* * *\end{array}$ & $\begin{array}{l}0.0001 \\
(3.2514) \\
* * *\end{array}$ & $\begin{array}{l}0.0003 \\
(4.1945) \\
* * *\end{array}$ & $\begin{array}{l}0.0000 \\
(3.5796) \\
* * *\end{array}$ & $\begin{array}{l}-0.0000 \\
(3.4563) \\
* * *\end{array}$ & $\begin{array}{l}0.0000 \\
(0.1504)\end{array}$ & $\begin{array}{l}0.0000 \\
(1.79967 \\
9)^{*}\end{array}$ \\
\hline Market share (log) & $\begin{array}{l}-0.2768 \\
(3.9964) \\
* * *\end{array}$ & $\begin{array}{l}0.0088 \\
(0.5105)\end{array}$ & $\begin{array}{l}1.7993 \\
(4.0964) \\
* * *\end{array}$ & $\begin{array}{l}0.1579 \\
(2.2234) \\
* *\end{array}$ & $\begin{array}{l}0.0898 \\
(1.7897) \\
*\end{array}$ & & $\begin{array}{l}0.1211 \\
(1.8211) \\
*\end{array}$ & $\begin{array}{l}0.6834 \\
(3.6581) \\
* * *\end{array}$ & $\begin{array}{l}0.0737 \\
(2.7190) \\
* * *\end{array}$ & $\begin{array}{l}-0.0353 \\
(4.2222) \\
* * *\end{array}$ & $\begin{array}{l}-0.0199 \\
(0.0700)\end{array}$ & $\begin{array}{l}0.0585 \\
(0.6568)\end{array}$ \\
\hline Concentration & $\begin{array}{l}1.4676 \\
(3.5063) \\
* * *\end{array}$ & $\begin{array}{l}-0.1262 \\
(0.8266)\end{array}$ & $\begin{array}{l}-6.3357 \\
(3.9682) \\
* * *\end{array}$ & & $\begin{array}{l}-1.3619 \\
(2.9798) \\
* * *\end{array}$ & $\begin{array}{l}0.1367 \\
(3.5461) \\
* * *\end{array}$ & $\begin{array}{l}-2.0629 \\
(2.5676) \\
* *\end{array}$ & $\begin{array}{l}-1.1661 \\
(2.3866) \\
* *\end{array}$ & $\begin{array}{l}-0.8468 \\
(3.1746) \\
* * *\end{array}$ & $\begin{array}{l}0.3041 \\
(4.2079) \\
* * *\end{array}$ & $\begin{array}{l}-0.5278 \\
(0.3223)\end{array}$ & $\begin{array}{l}-0.7791 \\
(1.2052)\end{array}$ \\
\hline $\begin{array}{l}\text { H-Statistic (Interest } \\
\text { revenue) }\end{array}$ & $\begin{array}{l}1.3858 \\
(4.6219) \\
* * *\end{array}$ & & & & & & & & & & & \\
\hline $\begin{array}{l}\text { H-Statistic (without } \\
\text { capital ratio) }\end{array}$ & & 0.1882 & & & & & & & & & & \\
\hline
\end{tabular}




\begin{tabular}{|c|c|c|c|c|c|c|c|c|c|c|c|c|}
\hline & (1) & (2) & (3) & (4) & (5) & (6) & (7) & (8) & (9) & (10) & (11) & (12) \\
\hline & & $\begin{array}{l}(3.5283) \\
* * *\end{array}$ & & & & & & & & & & \\
\hline $\begin{array}{l}\text { H-Statistic (Claessens } \\
\text { and Laeven) }\end{array}$ & & & $\begin{array}{l}13.9257 \\
(4.1348) \\
* * *\end{array}$ & & & & & & & & & \\
\hline $\begin{array}{l}\text { H-Statistic (Total } \\
\text { revenue) }\end{array}$ & & & & 0.3932 & 1.0372 & 0.1483 & 2.4793 & 2.1038 & 0.3427 & 0.0587 & 0.9072 & 0.5559 \\
\hline & & & & $\begin{array}{l}(3.8781) \\
* * *\end{array}$ & $\begin{array}{l}(5.3949) \\
* * *\end{array}$ & $\begin{array}{l}(4.4124) \\
* * *\end{array}$ & $\begin{array}{l}(3.4990) \\
* * *\end{array}$ & $\begin{array}{l}(4.6795) \\
* * *\end{array}$ & $\begin{array}{l}(4.8351) \\
* * *\end{array}$ & $\begin{array}{l}(1.6478) \\
*\end{array}$ & $\begin{array}{l}(2.0650) \\
* *\end{array}$ & $\begin{array}{l}(4.0000) \\
* * *\end{array}$ \\
\hline $\begin{array}{l}\text { Herfindahl-Hirschman } \\
\text { index }\end{array}$ & & & & $\begin{array}{l}-2.5643 \\
(2.4294) \\
* *\end{array}$ & & & & & & & & \\
\hline Observations & 8583 & 8583 & 8513 & 8583 & 8579 & 10248 & 7851 & 7545 & 8500 & 7893 & 8583 & 8583 \\
\hline Number of banks & 2631 & 2631 & 2590 & 2631 & 2629 & 2962 & 2342 & 2220 & 2604 & 2526 & 2631 & 2631 \\
\hline Wald $\chi^{2}$ & $\begin{array}{l}132.69 * \\
* *\end{array}$ & $\begin{array}{l}754.51^{*} \\
* *\end{array}$ & $49.26 * * *$ & $\begin{array}{l}291.86 * \\
* *\end{array}$ & $\begin{array}{l}257.44 * * \\
*\end{array}$ & $\begin{array}{l}169.30 * \\
* *\end{array}$ & $63.22 * * *$ & $\begin{array}{l}86.25 * * \\
*\end{array}$ & $\begin{array}{l}491.00 * * \\
*\end{array}$ & $\begin{array}{l}1812.48 \\
* * *\end{array}$ & $50.41 * * *$ & $\begin{array}{l}545.1515 \\
* * *\end{array}$ \\
\hline
\end{tabular}

Note: Absolute value of $\mathrm{z}$ statistics in parentheses. Constant term included but not reported. H-Statistic, concentration and market share instrumented using banking freedom, entry restrictions, and activity restrictions. Interbank ratio instrumented using pretax profit/total assets, cost/income ratio, and total assets (log). Setup (1) uses an alternative $\mathrm{H}$-Statistic obtained with interest revenue as dependent variable whereas Setup (2) uses an H-Statistic that does not contain the capital ratio in the HStatistic equation. Setup (3) uses the H-Statistics calculated by Claessens and Laeven (2004). Setup (4) employs the Herfindahl-Hirschman index as an alternative concentration measure. Setup (5) replaces the capital ratio by a ratio of equity to liabilities. Setup (6) drops all bank level controls. The sample is constrained to EU banks only in Setup (7) and we drop non-Euro currency area countries in Setup (8). We remove countries for which we have less than 20 bank-year observations in Setup (9) from the dataset and Setup (10) drops all observations for which the H-Statistic is not in equilibrium. Setup (11) clusters the errors on the country level. Setup (12) uses a bootstrapping procedure with 1,000 replications to account for the fact that the H-Statistic is estimated with standard error. * significant at 10\%; ** significant at $5 \%$; *** significant at $1 \%$. 
APPENDIX I: DATA

\begin{tabular}{|c|c|c|}
\hline Variable & Description & Source \\
\hline H-Statistic (H1) & $\begin{array}{l}\text { The H-Statistic }(\mathrm{H} 1) \text { is estimated using cross-sectional regressions } \\
\text { with total revenue for each country during the period } 1999-2004 \text {. }\end{array}$ & $\begin{array}{l}\text { BankScope; } \\
\text { authors' } \\
\text { calculations }\end{array}$ \\
\hline H-Statistic (H2) & $\begin{array}{l}\text { The H-Statistic }(\mathrm{H} 2) \text { is calculated using cross-sectional regressions } \\
\text { with interest revenue for each country during the period } 1999- \\
2004 \text {. }\end{array}$ & $\begin{array}{l}\text { BankScope; } \\
\text { authors' } \\
\text { calculations }\end{array}$ \\
\hline H-Statistic (H3) & $\begin{array}{l}\text { The H-Statistic (H3) is estimated using cross-sectional regressions } \\
\text { with total revenue for each country during the period } 1999-2004 \text {, } \\
\text { but it excludes the capital ratio as control variable. }\end{array}$ & $\begin{array}{l}\text { BankScope; } \\
\text { authors' } \\
\text { calculations }\end{array}$ \\
\hline $\begin{array}{l}\text { H-Statistic } \\
\text { (Claessens and } \\
\text { Laeven) }\end{array}$ & $\begin{array}{l}\text { The H-Statistics are calculated for } 50 \text { countries for the period } 1994 \\
\text { - } 2001 \text { using four alternative modeling setups. }\end{array}$ & $\begin{array}{l}\text { Claessens and } \\
\text { Laeven (2004) }\end{array}$ \\
\hline $\begin{array}{l}\text { Loan loss } \\
\text { provisions/Net } \\
\text { loans }\end{array}$ & Ratio of loan loss provisions to net loans & BankScope \\
\hline Leverage (inverse) & Ratio of equity capital to liabilities & BankScope \\
\hline Capital ratio & Ratio of equity capital to total assets & BankScope \\
\hline Interbank ratio & Ratio of deposits due from banks to deposits due to banks & BankScope \\
\hline $\begin{array}{l}\text { Pretax profit/Total } \\
\text { assets }\end{array}$ & Ratio of profit before tax to total assets & BankScope \\
\hline $\begin{array}{l}\text { Total assets, } \\
\text { deflated }\end{array}$ & Logarithm of total bank assets, deflated using the GDP deflator. & $\begin{array}{l}\text { BankScope, World } \\
\text { Bank Development } \\
\text { Indicators }\end{array}$ \\
\hline $\begin{array}{l}\text { 3-bank } \\
\text { concentration ratio }\end{array}$ & $\begin{array}{l}\text { Total assets held by the three largest banks in a country in relation } \\
\text { to total banking system assets. }\end{array}$ & $\begin{array}{l}\text { BankScope; } \\
\text { authors' } \\
\text { calculations }\end{array}$ \\
\hline $\begin{array}{l}\text { Herfindahl- } \\
\text { Hirschman index }\end{array}$ & $\begin{array}{l}\text { Index computed as the sum of the squared market shares for each } \\
\text { bank in a country. }\end{array}$ & $\begin{array}{l}\text { BankScope; } \\
\text { authors' } \\
\text { calculations }\end{array}$ \\
\hline Market share (log) & Market share held by the individual financial institution. & $\begin{array}{l}\text { BankScope; } \\
\text { authors' } \\
\text { calculations }\end{array}$ \\
\hline $\begin{array}{l}\text { Activity } \\
\text { restrictions }\end{array}$ & $\begin{array}{l}\text { The indicator is constructed as an index and takes on values } \\
\text { between (1) and (4), whereby the activities are classified as } \\
\text { unrestricted (1), permitted (2), restricted (3), or prohibited (4), } \\
\text { with possible index variation between four and sixteen. Higher } \\
\text { values indicate greater restrictions on bank activities and non- } \\
\text { financial ownership and control. }\end{array}$ & Barth et al. (2004) \\
\hline Entry restrictions & $\begin{array}{l}\text { The indicator is constructed as an index and takes on values } \\
\text { between (1) and (8), whereby a higher index value indicates } \\
\text { greater entry restrictions arising from legal requirements. }\end{array}$ & Barth et al. (2004) \\
\hline Banking freedom & $\begin{array}{l}\text { The index informs whether foreign banks are allowed to operate } \\
\text { freely, the difficulties when setting up domestic banks, and on } \\
\text { government influence over the allocation of credit. It is } \\
\text { constructed as index ranging from (1) to (5), whereby higher } \\
\text { values indicate fewer restrictions. }\end{array}$ & $\begin{array}{l}\text { Heritage } \\
\text { Foundation }\end{array}$ \\
\hline Real GDP growth & Rate of growth of the Gross Domestic Product. & $\begin{array}{l}\text { World Bank } \\
\text { Development } \\
\text { Indicators }\end{array}$ \\
\hline Real interest rate & $\begin{array}{l}\text { Real interest rate is the lending interest rate adjusted for inflation } \\
\text { as measured by the GDP deflator. }\end{array}$ & $\begin{array}{l}\text { World Bank } \\
\text { Development } \\
\text { Indicators }\end{array}$ \\
\hline
\end{tabular}




\begin{tabular}{|c|c|c|}
\hline Variable & Description & Source \\
\hline Inflation & Rate of change of the GDP deflator. & $\begin{array}{l}\text { World Bank } \\
\text { Development } \\
\text { Indicators }\end{array}$ \\
\hline GDP per capita & Ratio of GDP to population & $\begin{array}{l}\text { World Bank } \\
\text { Development } \\
\text { Indicators }\end{array}$ \\
\hline $\begin{array}{l}\text { Non-performing } \\
\text { loans/Total loans }\end{array}$ & $\begin{array}{l}\text { Proportion of non-performing loans to total loans in a banking } \\
\text { system. }\end{array}$ & $\begin{array}{l}\text { World Bank } \\
\text { Development } \\
\text { Indicators }\end{array}$ \\
\hline $\begin{array}{l}\text { Market } \\
\text { capitalization/GDP }\end{array}$ & Stock market capitalization to Gross Domestic Product. & $\begin{array}{l}\text { World Bank } \\
\text { Development } \\
\text { Indicators }\end{array}$ \\
\hline Credit growth & $\begin{array}{l}\text { Growth of the ratio of domestic credit provided by the banking } \\
\text { sector to GDP. }\end{array}$ & $\begin{array}{l}\text { World Bank } \\
\text { Development } \\
\text { Indicator; authors' } \\
\text { calculations }\end{array}$ \\
\hline $\begin{array}{l}\text { Size of banking } \\
\text { sector relative to } \\
\text { stock market }\end{array}$ & $\begin{array}{l}\text { Proportion of the banking sector assets to stock market } \\
\text { capitalization. }\end{array}$ & Beck et al. (2000) \\
\hline $\begin{array}{l}\text { Life insurance } \\
\text { penetration }\end{array}$ & $\begin{array}{l}\text { Measure for the competition from the life insurance industry } \\
\text { calculated as the ratio of the volume of life insurance premiums to } \\
\text { GDP. }\end{array}$ & Beck et al. (2000) \\
\hline $\begin{array}{l}\text { Number of } \\
\text { banks/population }\end{array}$ & $\begin{array}{l}\text { The logarithm of the ratio of the number of banks in the country to } \\
\text { the total population in the country, measured as at } 2001 \text {. }\end{array}$ & $\begin{array}{l}\text { Barth et al. (2001) } \\
\text { and World Bank } \\
\text { Development } \\
\text { Indicators; authors' } \\
\text { calculations }\end{array}$ \\
\hline British legal origin & $\begin{array}{l}\text { Dummy variable that takes on the value one if the country's legal } \\
\text { system is of British origin or zero otherwise }\end{array}$ & $\begin{array}{l}\text { La Porta et al. } \\
\text { (1998) }\end{array}$ \\
\hline French legal origin & $\begin{array}{l}\text { Dummy variable that takes on the value one if the country's legal } \\
\text { system is of French origin or zero otherwise }\end{array}$ & $\begin{array}{l}\text { La Porta et al. } \\
\text { (1998) }\end{array}$ \\
\hline $\begin{array}{l}\text { German legal } \\
\text { origin }\end{array}$ & $\begin{array}{l}\text { Dummy variable that takes on the value one if the country's legal } \\
\text { system is of German origin or zero otherwise }\end{array}$ & $\begin{array}{l}\text { La Porta et al. } \\
\text { (1998) }\end{array}$ \\
\hline $\begin{array}{l}\text { Scandinavian legal } \\
\text { origin }\end{array}$ & $\begin{array}{l}\text { Dummy variable that takes on the value one if the country's legal } \\
\text { system is of Scandinavian origin or zero otherwise }\end{array}$ & $\begin{array}{l}\text { La Porta et al. } \\
\text { (1998) }\end{array}$ \\
\hline Rule of law & $\begin{array}{l}\text { Measure for the strength of the institutional environment. The } \\
\text { index is increasing in the quality of the institutional environment } \\
\text { and ranges between zero and six. }\end{array}$ & Beck et al. (2000) \\
\hline $\begin{array}{l}\text { Government } \\
\text { ownership }\end{array}$ & $\begin{array}{l}\text { Bank ownership measured as the proportion of bank assets held by } \\
\text { government. }\end{array}$ & $\begin{array}{l}\text { La Porta et al. } \\
\text { (2002) }\end{array}$ \\
\hline $\begin{array}{l}\text { Foreign bank } \\
\text { ownership }\end{array}$ & $\begin{array}{l}\text { Bank ownership measured as the proportion of bank assets held by } \\
\text { foreigners. }\end{array}$ & Barth et al. (2001) \\
\hline Moral hazard index & $\begin{array}{l}\text { Indicator for generosity of deposit insurance schemes calculated as } \\
\text { the first principal component of the design features: co-insurance, } \\
\text { coverage of FX and interbank deposits, membership, management, } \\
\text { type, source of funding, level of explicit coverage, presence of } \\
\text { risk-based premiums, deposit insurer's power to revoke a bank } \\
\text { license and its ability to intervene a bank. }\end{array}$ & $\begin{array}{l}\text { Demirgüç-Kunt } \\
\text { and Detragiache } \\
\text { (2002) }\end{array}$ \\
\hline $\begin{array}{l}\text { Capital regulatory } \\
\text { index }\end{array}$ & $\begin{array}{l}\text { Index of capital stringency calculated as initial capital stringency } \\
\text { and overall capital stringency. }\end{array}$ & Barth et al. (2004) \\
\hline $\begin{array}{l}\text { Shareholder rights } \\
\text { index }\end{array}$ & $\begin{array}{l}\text { Summary index for the emphasis on shareholder rights, with } \\
\text { higher values indicating more shareholder rights. }\end{array}$ & $\begin{array}{l}\text { La Porta et al. } \\
\text { (1998) }\end{array}$ \\
\hline
\end{tabular}




\section{APPENDIX II. CORRELATION MATRIX (INSTRUMENTS)}

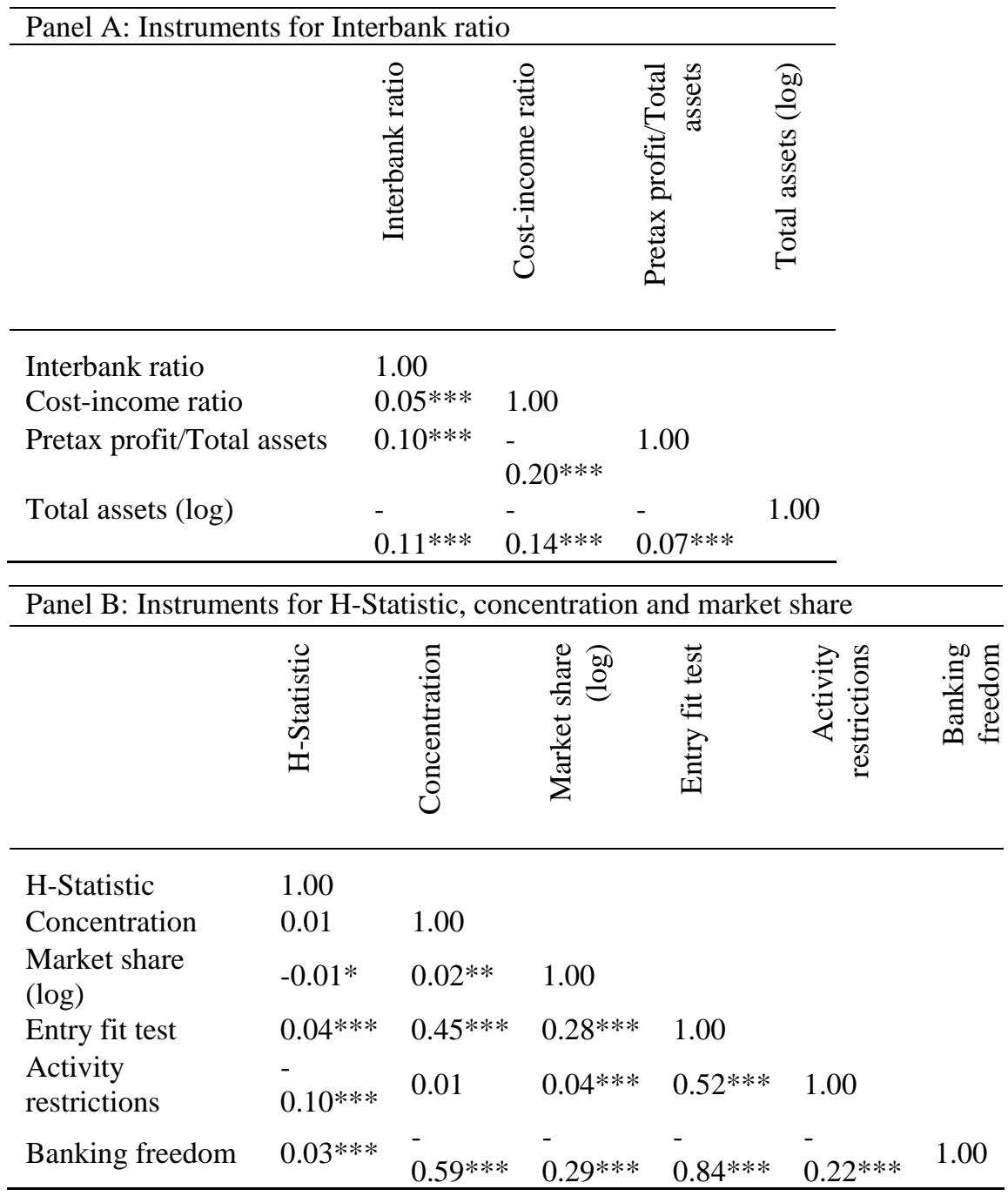




\section{APPENDIX III. FIRST-STAGE REGRESSIONS}

\begin{tabular}{|c|c|c|c|c|}
\hline & (1) & (2) & (3) & (4) \\
\hline & H-Statistic & Concentration & Market share (log) & Interbank ratio \\
\hline \multirow[t]{2}{*}{ Pretax profit/Total assets } & 0.113 & 0.030 & 0.341 & 3.779 \\
\hline & (1.1554) & $(2.0524)^{* *}$ & $(2.9315)^{* * *}$ & $(3.3812) * * *$ \\
\hline \multirow[t]{2}{*}{ Loan loss provisions/Net loans } & 0.161 & -0.029 & -0.211 & -1.507 \\
\hline & (1.1854) & $(0.6767)$ & $(0.6663)$ & $(0.8418)$ \\
\hline \multirow[t]{2}{*}{ Cost to income ratio } & 0.022 & -0.006 & -0.063 & 0.251 \\
\hline & $(3.1732)^{* * *}$ & $(5.4317)^{* * *}$ & $(7.2330)^{* * *}$ & $(3.6192) * * *$ \\
\hline \multirow[t]{2}{*}{ Total assets, deflated } & 0.012 & -0.006 & 0.935 & -0.148 \\
\hline & $(9.3415) * * *$ & $(10.6026)^{* * *}$ & $(246.0027)^{* * *}$ & $(6.7269) * * *$ \\
\hline \multirow[t]{2}{*}{ Entry fit test } & 0.079 & 0.070 & 0.574 & -0.933 \\
\hline & $(7.1341)^{* * *}$ & $(22.3878)^{* * *}$ & $(26.2809)^{* * *}$ & $(6.8145)^{* * *}$ \\
\hline \multirow{2}{*}{ Activity restrictions } & -0.009 & 0.008 & 0.069 & 0.404 \\
\hline & $(2.6506)^{* * *}$ & $(6.0972) * * *$ & $(7.5473)^{* * *}$ & $(7.1339) * * *$ \\
\hline \multirow[t]{2}{*}{ Banking freedom } & -0.001 & -0.041 & 0.056 & -0.728 \\
\hline & $(0.0489)$ & $(25.6495)^{* * *}$ & $(4.4167)^{* * *}$ & $(6.6572) * * *$ \\
\hline \multirow[t]{2}{*}{ GDP growth } & -4.966 & 0.129 & 1.730 & -3.836 \\
\hline & $(23.3762)^{* * *}$ & $(4.9919) * * *$ & $(8.4225)^{* * *}$ & $(2.4950)^{* *}$ \\
\hline \multirow[t]{2}{*}{ Inflation } & -7.579 & 2.547 & 4.681 & 0.068 \\
\hline & $(20.8269) * * *$ & $(53.0407)^{* * *}$ & $(12.4050)^{* * *}$ & $(0.0239)$ \\
\hline \multirow[t]{2}{*}{ Real interest rate } & -0.073 & 2.260 & -8.713 & -10.365 \\
\hline & $(0.2953)$ & $(63.2123)^{* * *}$ & $(31.7802)^{* * *}$ & $(5.1928) * * *$ \\
\hline \multirow[t]{2}{*}{ GDP per capita } & -0.000 & 0.000 & 0.000 & -0.000 \\
\hline & $(3.6517)^{* * *}$ & $(113.3912)^{* * *}$ & $(18.3807)^{* * *}$ & $(2.0810)^{* *}$ \\
\hline Observations & 9724 & 9764 & 9757 & 8617 \\
\hline Number of banks & 2837 & 2843 & 2843 & 2636 \\
\hline Wald $\chi^{2}$ & $1373.73^{* * *}$ & $51390.69 * * *$ & $75066.17 * * *$ & $683.49 * * *$ \\
\hline $\begin{array}{l}\text { First stage } F \text {-Statistic for } \\
\text { instruments }\end{array}$ & $330.73 * * *$ & $5269.18 * * *$ & $61613.25^{* * *}$ & $181.02 * * *$ \\
\hline
\end{tabular}

Constant term included but not reported. Absolute value of $\mathrm{z}$ statistics in parentheses. * significant at $10 \%$; $* *$ significant at $5 \%$; $* * *$ significant at $1 \%$. 


\section{APPENDiX IV. FURTHER ROBUSTNESS CHECKS}

\begin{tabular}{|c|c|c|c|c|c|c|}
\hline & $(1)$ & $(2)$ & (3) & $(4)$ & (5) & (6) \\
\hline Pretax profit/Total assets & $\begin{array}{l}0.6100 \\
(1.3053)\end{array}$ & $\begin{array}{l}0.9198 \\
(9.8823)^{* * *}\end{array}$ & $\begin{array}{l}0.8360 \\
(7.1053)^{* * *}\end{array}$ & $\begin{array}{l}0.6566 \\
(4.7188)^{* * *}\end{array}$ & $\begin{array}{l}0.9549 \\
(7.3376)^{* * *}\end{array}$ & $\begin{array}{l}0.8505 \\
(7.2703)^{* * *}\end{array}$ \\
\hline Interbank ratio & $\begin{array}{l}-0.0073 \\
(0.2077)\end{array}$ & $\begin{array}{l}0.0436 \\
(4.7093)^{* * *}\end{array}$ & $\begin{array}{l}0.0670 \\
(6.5965) * * *\end{array}$ & $\begin{array}{l}0.0806 \\
(6.5727)^{* * *}\end{array}$ & $\begin{array}{l}0.0431 \\
(3.6043)^{* * *}\end{array}$ & $\begin{array}{l}0.0650 \\
(6.4576)^{* * *}\end{array}$ \\
\hline Loan loss provisions/Net loans & $\begin{array}{l}-0.0655 \\
(0.2225)\end{array}$ & $\begin{array}{l}0.3257 \\
(4.2333)^{* * *}\end{array}$ & $\begin{array}{l}0.3482 \\
(3.3324)^{* * *}\end{array}$ & $\begin{array}{l}0.4006 \\
(3.4494)^{* * *}\end{array}$ & $\begin{array}{l}0.2286 \\
(1.8589) *\end{array}$ & $\begin{array}{l}0.3396 \\
(3.2746)^{* * *}\end{array}$ \\
\hline Total assets, deflated & $\begin{array}{l}-2.8823 \\
(2.5928)^{* * *}\end{array}$ & $\begin{array}{l}0.0245 \\
(0.8622)\end{array}$ & $\begin{array}{l}-0.0289 \\
(1.7402)^{*}\end{array}$ & $\begin{array}{l}-0.0759 \\
(3.6191)^{* * *}\end{array}$ & $\begin{array}{l}0.0270 \\
(1.0689)\end{array}$ & $\begin{array}{l}-0.0166 \\
(0.9002)\end{array}$ \\
\hline GDP growth & $\begin{array}{l}0.5440 \\
(0.5093)\end{array}$ & $\begin{array}{l}2.0402 \\
(1.7203)^{*}\end{array}$ & $\begin{array}{l}1.5549 \\
(4.3203)^{* * *}\end{array}$ & $\begin{array}{l}0.8115 \\
(2.5648)^{* *}\end{array}$ & $\begin{array}{l}1.0597 \\
(3.4134)^{* * *}\end{array}$ & $\begin{array}{l}1.8273 \\
(5.0041)^{* * *}\end{array}$ \\
\hline Inflation & $\begin{array}{l}-33.2188 \\
(2.0641)^{* *}\end{array}$ & $\begin{array}{l}3.4486 \\
(5.0689)^{* * *}\end{array}$ & $\begin{array}{l}2.5125 \\
(3.8630)^{* * *}\end{array}$ & $\begin{array}{l}1.5217 \\
(2.5872)^{* * *}\end{array}$ & $\begin{array}{l}2.0810 \\
(2.3999)^{* *}\end{array}$ & $\begin{array}{l}2.9406 \\
(4.4963)^{* * *}\end{array}$ \\
\hline Real interest rate & $\begin{array}{l}11.3406 \\
(1.8780)^{*}\end{array}$ & $\begin{array}{l}0.6744 \\
(2.0218)^{* *}\end{array}$ & $\begin{array}{l}1.4163 \\
(3.4962)^{* * *}\end{array}$ & $\begin{array}{l}2.2407 \\
(4.3487)^{* * *}\end{array}$ & $\begin{array}{l}0.6705 \\
(1.6229)\end{array}$ & $\begin{array}{l}1.2257 \\
(2.9394) * * *\end{array}$ \\
\hline Market share (log) & $\begin{array}{l}2.8418 \\
(2.5500)^{* *}\end{array}$ & $\begin{array}{l}-0.0273 \\
(1.0007)\end{array}$ & $\begin{array}{l}0.0280 \\
(1.6462)^{*}\end{array}$ & $\begin{array}{l}0.0802 \\
(3.6875)^{* * *}\end{array}$ & $\begin{array}{l}-0.0333 \\
(1.2734)\end{array}$ & $\begin{array}{l}0.0150 \\
(0.7952)\end{array}$ \\
\hline Concentration & $\begin{array}{l}-9.5573 \\
(3.2209)^{* * *}\end{array}$ & $\begin{array}{l}0.2242 \\
(1.0958)\end{array}$ & $\begin{array}{l}-0.4601 \\
(3.0449)^{* * *}\end{array}$ & $\begin{array}{l}-0.6745 \\
(3.2538)^{* * *}\end{array}$ & $\begin{array}{l}0.2726 \\
(1.2581)\end{array}$ & $\begin{array}{l}-0.2708 \\
(1.5760)\end{array}$ \\
\hline H-Statistic (Total revenue) & $\begin{array}{l}1.3942 \\
(2.1816)^{* *}\end{array}$ & $\begin{array}{l}0.1429 \\
(2.3709)^{* *}\end{array}$ & $\begin{array}{l}0.2911 \\
(4.0927)^{* * *}\end{array}$ & $\begin{array}{l}0.2245 \\
(3.4145)^{* * *}\end{array}$ & $\begin{array}{l}0.1013 \\
(2.1192)^{* *}\end{array}$ & $\begin{array}{l}0.3220 \\
(4.4686)^{* * *}\end{array}$ \\
\hline GDP per capita & $\begin{array}{l}0.0009 \\
(2.4866)^{* *}\end{array}$ & $\begin{array}{l}-0.0000 \\
(0.2992)\end{array}$ & $\begin{array}{l}0.0000 \\
(4.2567)^{* * *}\end{array}$ & $\begin{array}{l}0.0000 \\
(3.5506)^{* * *}\end{array}$ & $\begin{array}{l}-0.0000 \\
(0.7480)\end{array}$ & $\begin{array}{l}0.0000 \\
(2.3003)^{* *}\end{array}$ \\
\hline $\begin{array}{l}\text { Standard deviation GDP } \\
\text { growth }\end{array}$ & & & $\begin{array}{l}-9.1493 \\
(3.5580)^{* * *}\end{array}$ & & & \\
\hline Country dummies & Yes & No & No & No & No & No \\
\hline Year dummies & No & Yes & No & No & No & No \\
\hline Observations & 8583 & 8583 & 8583 & 8388 & 3278 & 8582 \\
\hline Number of banks & 2631 & 2631 & 2631 & 2556 & 1059 & 2631 \\
\hline Wald $\chi^{2}$ & $116.12^{* * *}$ & $1147.84 * * *$ & $615.150^{* * *}$ & $475.18^{* * *}$ & $264.31 * * *$ & $617.50 * * *$ \\
\hline
\end{tabular}

Constant term included but not reported. Absolute value of $\mathrm{z}$ statistics in parentheses. H-Statistic, concentration and market share instrumented using entry restrictions, banking freedom and activity restrictions. Interbank ratio instrumented using pretax profit/total assets, cost/income ratio, and total assets (log). Setup (1) includes country dummies and Setup (2) includes year dummies. Setup (3) includes the standard deviation of GDP growth to control for macroeconomic volatility. Setup (4) controls for survivorship bias and Setup (5) excludes German co-operative and German savings banks. Setup (6) excludes banks with negative capital ratios or where the capital ratio equals one. * significant at $10 \%$; ** significant at $5 \%$; ** significant at $1 \%$. 


\section{REFERENCES}

Allen, F., E. Carletti, and R. Marquez, 2005, Credit market competition and capital regulation. R. H. Smith School of Business, Working Paper No. RHS-06-037

Allen, F., and D. Gale, 2004, Competition and financial stability. Journal of Money, Credit, and Banking, Vol. 36 (3), pp. 453-480

Ayuso, J., D. Perez, and J. Saurina, 2004, Are capital buffers procyclical? Evidence from Spanish panel data. Journal of Financial Intermediation, Vol. 13, pp. 249-264

Barth, J. R., G. Caprio, Jr., and R. Levine, 2001, The regulation and supervision of banks around the world—A new database (Vol.1). World Bank. Mimeo.

— 2004, Bank regulation and supervision: What works best? Journal of Financial Intermediation, Vol. 13, pp. 205-248

Baumol, W., J. C. Panzar, and R. D. Willig, 1982, Contestable markets and the theory of industry structure. New York: Harcourt Brace Jovanovic

Beck, T., A. Demirgüç-Kunt, and R. Levine, 2000, A New Database on Financial Development and Structure, World Bank Economic Review, Vol. 14, pp. 597-605

— 2006a, Bank concentration, competition, and crises: First results. Journal of Banking and Finance, Vol. 30, pp. 1581-1603

— 2006b, Bank Concentration and Fragility: Impact and Mechanics. In: Carey, M. and R. Stulz, 2006, The Risks of financial institutions. Cambridge, Massachusetts: National Bureau of Economic Research, pp. 193-234

Berger, A. N., G. R. G. Clarke, R. Cull, L. Klapper, G. F. Udell, 2005, Corporate governance and bank performance: A joint analysis of the static, selection, and dynamic effects of domestic, foreign, and state ownership. Journal of Banking and Finance, Vol. 29, pp. 2179-2221

Berger, A. N., A. Demirgüç-Kunt, R. Levine, and J. G. Haubrich, 2004, Bank concentration and competition: An evolution in the making. Journal of Money, Credit, and Banking, Vol. 36 (3), pp. 434-450

Bikker, J. A., 2004, Competition and efficiency in a unified European banking market. Cheltenham: Edward Elgar

—_ and K. Haaf, 2002, Competition, concentration and their relationship: An empirical analysis of the banking industry. Journal of Banking and Finance, Vol. 26, pp. 21912214 
Bolt, W., and A. Tieman, 2004, Banking Competition, Risk and Regulation. Scandinavian Journal of Economics, Vol. 106 (4), pp. 783-804

Bongini, P., S. Claessens, and G. Ferri, 2001, The Political Economy of Distress in East Asian Financial Institutions. Journal of Financial Services Research, Vol. 19 (1), pp. $5-25$

Boyd, J. H., and G. de Nicoló, 2005, The theory of bank risk-taking and competition revisited. Journal of Finance, Vol. 60, pp. 1329-1342 , and A. M. Jalal, 2006, Bank risk-taking and competition revisited: New theory and new evidence. IMF Working Paper 06/297, Washington, D. C.: International Monetary Fund

Caminal, R. and C. Matutes, 2002, Market power and bank failures. International Journal of Industrial Organisation, Vol. 20 (9), pp. 1341-1361

Cetorelli, N., 1999, Competitive analysis in banking: Appraisal of the methodologies. Economic Perspectives, Federal Reserve Bank of Chicago, pp. 2-15

Claessens, S., and L. Laeven, 2004, What drives bank competition? Some international evidence. Journal of Money, Credit, and Banking, Vol. 36 (3), pp. 563-583

De Bandt, O., and E. P. Davis, 2000, Competition, contestability and market structure in European banking sectors on the eve of EMU. Journal of Banking and Finance, Vol. 24, pp. 1045-1066

Dell'Ariccia, G., and R. S. Marquez, 2006, Lending Booms and Lending Standards. Journal of Finance, Vol. 61, pp. 2511-2546

Demirgüç-Kunt, A., and E. Detragiache, 1998, The determinants of banking crises in developing and developed countries. IMF Staff Papers, Vol. 45 (1), pp. 81-109

_ investigation. Journal of Monetary Economics, Vol. 49, pp. 1373-1406

— 2005, Cross-country empirical studies of systemic bank distress: A survey. IMF Working Paper 05/96, Washington, D. C.: International Monetary Fund

Demirgüç-Kunt, A., L. Laeven, and R. Levine, 2004, Regulations, market structure, institutions, and the cost of financial intermediation. Journal of Money, Credit, and Banking, Vol. 36, pp. 593-622

Demsetz, H., 1973, Industry structure, market rivalry, and public policy. Journal of Law and Economics, Vol. 16, pp. 1-9 
Demsetz, R. S., and P. E. Strahan, 1997, Diversification, size, and risk at U.S. bank holding companies. Journal of Money, Credit, and Banking, Vol. 29, pp. 300-313

Dinç I. S., 2000, Bank reputation, bank commitment, and the effects of competition in credit markets. Review of Financial Studies, Vol. 13, pp. 781-812

Eichengreen, B. M., and C. Arteta, 2000, Banking crises in emerging markets: Presumptions and evidence. Center for International and Development Economics Research, University of California, Berkeley, Paper C00’115

Flannery, M., and K. Rangan, 2004, What caused the capital build-up of the 1990? Working Paper No. 2004-03-03. FDIC Center for Financial Research

Gan, J., 2004, Banking market structure and financial stability: Evidence from the Texas real estate crisis in the 1980s. Journal of Financial Economics, Vol. 73, pp. 567-601

Gilbert, R. A., 1984, Bank market structure and competition: A survey. Journal of Money, Credit, and Banking, Vol. 16, pp. 617-645

Gropp, R., and J. Vesala, 2004, Deposit insurance, moral hazard, and market monitoring. Review of Finance, Vol. 8, pp. 571-602

Hellman, T. F., K. Murdoch, and J. E. Stiglitz, 2000, Liberalization, moral hazard in banking and prudential regulation: Are capital requirements enough? American Economic Review, Vol. 90 (1), pp. 147-165

Hortlund, P., 2005, Do Inflation and High Taxes Increase Bank Leverage? Stockholm School of Economics Working Paper Series in Economics and Finance, No 612

Hutchinson, M. M., and K. M. McDill, 1999, Are All Banking Crises Alike? The Japanese Experience in International Comparison. Journal of the Japanese and International Economies, Vol. 13, pp. 155-180

International Monetary Fund, 2001, Financial sector consolidation in emerging markets, Chapter V, International Capital Market Report, Washington, D.C.: International Monetary Fund

— 2004, Compilation Guide on Financial Soundness Indicators, Washington, D.C.: International Monetary Fund, available at http://www.imf.org/external/np/sta/fsi/eng/2004/guide/index.htm

Keeley, M. C., 1990, Deposit insurance, risk and market power in banking. American Economic Review, Vol. 80, pp. 1183-1200 
La Porta, R., F. Lopez-de-Silanes, and A. Shleifer, 1998, Law and finance. Journal of Political Economy, Vol. 106, pp. 1113-1155

— , 2002, Government ownership of banks. Journal of Finance, Vol. 57 (1), pp. 265-301

Laeven, L., and G. Majoni, 2003, Loan loss provisioning and economic slowdowns: Too much, too late? Journal of Financial Intermediation, Vol. 12, pp. 178-197

Martin, D., 1977, Early Warning of Bank Failure: A Logit Regression Approach. Journal of Banking and Finance, Vol. 1, pp. 249-276

Mercieca, S., K. Schaeck, and S. Wolfe, 2007, Small banks in Europe: Benefits from diversification? Journal of Banking and Finance, Vol. 31, pp. 1975-1998.

Mishkin, F. S., 1999, Financial consolidation: Dangers and opportunities. Journal of Banking and Finance, Vol. 23, pp. 675-691

Molyneux, P., J. Thornton, and M. Lloyd-Williams, 1996, Competition and market contestability in Japanese commercial banking. Journal of Economics and Business, Vol. 48, pp. 33-45

Molyneux, P., D. M. Lloyd-Williams, and J. Thornton, 1994, Competitive conditions in European banking. Journal of Banking and Finance, Vol. 18, pp. 445-459

Myers, S. C., and N. S. Majluf, 1984, Corporate financing and investment decisions when firms have information investors do not have. Journal of Financial Economics, Vol. 13, pp. 187-221

Nier, E., and U. Baumann, 2006, Market discipline, disclosure and moral hazard in banking. Journal of Financial Intermediation, Vol. 15, pp. 332-361

Panzar, J. C., and J. N. Rosse, 1987, Testing for monopoly equilibrium. Journal of Industrial Economics, Vol. 35, pp. 443-456

Repullo, R., 2004, Capital requirements, market power, and risk-taking in banking. Journal of Financial Intermediation, Vol. 13, pp. 156-182

Ruckes, M., 2004, Bank competition and credit standards. Review of Financial Studies, Vol. 17, pp. 1073-1102

Schaeck, K., M. Čihák, and S. Wolfe, 2006, Are more competitive banking systems more stable? IMF Working Paper, WP/06/143, Washington, D.C.: International Monetary Fund 
Shaffer, S., 2004a, Comment on "What drives bank competition? Some international evidence" by Stijn Claessens and Luc Laeven. Journal of Money, Credit, and Banking, Vol. 36 (3), pp. 585-592

Shaffer, S., 2004b, Patterns of competition in banking. Journal of Economics and Business, Vol. 56, pp. 287-313

Smith, B. D., 1984, Private information, deposit interest rates, and the 'stability' of the banking system. Journal of Monetary Economics, Vol. 14, pp. 293-317

The World Bank - International Monetary Fund, 2005, Financial sector assessment: A handbook. Washington, D. C.: The World Bank/International Monetary Fund

Verbeek, M., 2004, A guide to modern econometrics. 2nd ed. Chichester: John Wiley and Sons

Vesala, J., 1995, Testing for competition in banking: Behavioral evidence from Finland. Helsinki: Bank of Finland 